\title{
Classification of $\mathrm{H}_{2} \mathrm{O}_{2}$ as a Neuromodulator that Regulates Striatal Dopamine Release on a Subsecond Time Scale
}

\author{
Jyoti C. Patel ${ }^{* \dagger} \dagger$ and Margaret E. Rice ${ }^{\dagger, \dagger}$
}

${ }^{\dagger}$ Department of Neurosurgery, ${ }^{\ddagger}$ Department of Physiology and Neuroscience, New York University School of Medicine, 550 First Avenue, New York, New York 10016, United States

ABSTRACT: Here we review evidence that the reactive oxygen species, hydrogen peroxide $\left(\mathrm{H}_{2} \mathrm{O}_{2}\right)$, meets the criteria for classification as a neuromodulator through its effects on striatal dopamine (DA) release. This evidence was obtained using fast-scan cyclic voltammetry to detect evoked DA release in striatal slices, along with whole-cell and fluorescence imaging to monitor cellular activity and $\mathrm{H}_{2} \mathrm{O}_{2}$ generation in striatal medium spiny neurons (MSNs). The data show that (1) exogenous $\mathrm{H}_{2} \mathrm{O}_{2}$ suppresses DA release in dorsal striatum and nucleus accumbens shell and the same effect is seen with elevation of endogenous $\mathrm{H}_{2} \mathrm{O}_{2}$ levels; (2) $\mathrm{H}_{2} \mathrm{O}_{2}$ is generated downstream from glutamatergic AMPA receptor activation in MSNs, but not DA axons; (3) generation of modulatory

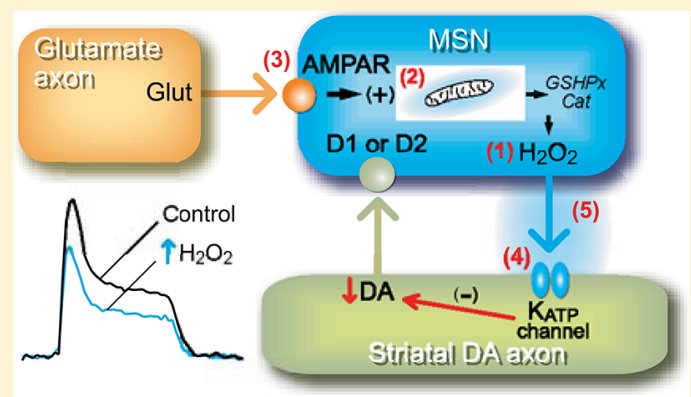
$\mathrm{H}_{2} \mathrm{O}_{2}$ is activity dependent; (4) $\mathrm{H}_{2} \mathrm{O}_{2}$ generated in MSNs diffuses to DA axons to cause transient DA release suppression by activating ATP-sensitive $\mathrm{K}^{+}\left(\mathrm{K}_{\mathrm{ATP}}\right)$ channels on DA axons; and (5) the amplitude of $\mathrm{H}_{2} \mathrm{O}_{2}$-dependent inhibition of DA release is attenuated by enzymatic degradation of $\mathrm{H}_{2} \mathrm{O}_{2}$, but the subsecond time course is determined by $\mathrm{H}_{2} \mathrm{O}_{2}$ diffusion rate and/or $\mathrm{K}_{\text {ATP- }}$ channel kinetics. In the dorsal striatum, neuromodulatory $\mathrm{H}_{2} \mathrm{O}_{2}$ is an intermediate in the regulation of DA release by the classical neurotransmitters glutamate and GABA, as well as other neuromodulators, including cannabinoids. However, modulatory actions of $\mathrm{H}_{2} \mathrm{O}_{2}$ occur in other regions and cell types, as well, consistent with the widespread expression of $\mathrm{K}_{\mathrm{ATP}}$ and other $\mathrm{H}_{2} \mathrm{O}_{2}$ sensitive channels throughout the CNS.

KEYWORDS: Brain slices, dorsal striatum, fast-scan cyclic voltammetry, fluorescence imaging, transmitter release, review

$\mathrm{T}$ he striatum is the largest component of the basal ganglia and receives dense dopamine (DA) innervation from midbrain DA neurons in the substantia nigra pars compacta $(\mathrm{SNc})$ and ventral tegmental area (VTA). ${ }^{1}$ The primary targets of these DA afferents are medium spiny neurons (MSNs) that constitute over $90 \%$ of the striatal neuronal population and are the main output neurons of this region. Axons arising from midbrain DA neurons form symmetric synapses on MSNs, primarily on spine necks, adjacent to glutamatergic input to spine heads. ${ }^{2,3}$ This architectural arrangement enables DA to modulate glutamate-induced MSN excitability with differential outcomes according to whether the target MSN also expresses DA D1 receptors (D1Rs) or DA D2 receptors (D2Rs); DA enhances MSN excitability and up-state MSN spiking via D1Rs and decreases these via D2Rs. ${ }^{4}$ Thus, converging glutamatergic and dopaminergic afferents control striatal output at the level of individual spines to regulate motor and cognitive function. ${ }^{4-6}$ It is relevant to note that D1Rs and D2Rs are predominantly extrasynaptic, ${ }^{7}$ so that rapid electrochemical measurements of extracellular DA concentration $\left([\mathrm{DA}]_{\mathrm{o}}\right)$ can provide a direct index of DA transmission (e.g., 8-10).

The crucial role that DA plays in normal motor behavior has been illuminated by the findings that disturbances in DA function contribute to basal-ganglia circuit dysfunction and that DA depletion leads to the motor deficits of Parkinson's disease. $^{11-13}$ Thus, elucidating factors that regulate DA release in the striatum is of relevance for understanding the role of DA in normal brain function, as well as for providing therapeutic insight for neuropathological conditions like Parkinson's disease.

Our laboratory examines the regulation of striatal DA release using fast-scan cyclic voltammetry (FCV) with carbon-fiber microelectrodes. Because FCV detects dynamic changes in $[\mathrm{DA}]_{\mathrm{o}}$ with high temporal and spatial resolution, this technique is ideally suited to determine factors that influence the amplitude, duration, and sphere of influence of DA signaling. ${ }^{14-17}$ Basic factors that we have examined include the pattern of stimulation, $\mathrm{Ca}^{2+}$-dependence of DA release, inhibition of DA release by presynaptic DA autoreceptors, and DA clearance by the DA transporter (DAT); we have also examined the effect of a number of local neurotransmitters and neuromodulators that can act on DA axons either directly or indirectly to alter evoked $[\mathrm{DA}]_{\mathrm{o}}$ (for review, see ref 10 ).

One unconventional and under-appreciated modulator of striatal DA release is hydrogen peroxide $\left(\mathrm{H}_{2} \mathrm{O}_{2}\right) . \mathrm{H}_{2} \mathrm{O}_{2}$ is most commonly known as a reactive oxygen species (ROS) that is formed from cellular oxidative metabolism and is often viewed as being toxic. However, $\mathrm{H}_{2} \mathrm{O}_{2}$ is not a free radical and, consequently, is not as reactive as other ROS. ${ }^{18}$ In fact,

Received: August 17, 2012

Accepted: October 15, 2012

Published: November 8, 2012 
increasing evidence indicates that $\mathrm{H}_{2} \mathrm{O}_{2}$ plays an important role in normal cellular signaling processes, as well as in the modulation of transmitter release. ${ }^{19}$

Here we review the evidence that endogenous $\mathrm{H}_{2} \mathrm{O}_{2}$ fulfills criteria for classification as a neuromodulator through its actions on striatal DA release. We would note, however, that actions of $\mathrm{H}_{2} \mathrm{O}_{2}$ are not limited to DA axons, and possibly not even to the brain, as summarized in Concluding Remarks. Criteria often used to classify a molecule as a transmitter or modulator include the following: (1) same response elicited by the exogenous and endogenous substance; (2) synthesis of the substance within a releasing cell; (3) release in response to depolarization or receptor activation; (4) receptor/sensor for the substance at a target site; and (5) mechanism for deactivation. Using a combination of FCV to detect evoked $[\mathrm{DA}]_{\mathrm{o}}$ in striatal slices, whole-cell recording of striatal MSN activity, and fluorescence imaging to monitor $\mathrm{H}_{2} \mathrm{O}_{2}$ generation, we have shown that $\mathrm{H}_{2} \mathrm{O}_{2}$ is generated downstream from glutamatergic AMPA receptor (AMPAR) activation in MSNs, and then diffuses to DA axons where it causes transient suppression of striatal DA release through activation of ATPsensitive $\mathrm{K}^{+}\left(\mathrm{K}_{\text {ATP }}\right)$ channels on DA axons. Through this regulatory pathway, $\mathrm{H}_{2} \mathrm{O}_{2}$ acts as a key intermediate for DA modulation by glutamate and GABA, as well as other neuromodulators including the cannabinoids.

\section{CRITERION 1: BOTH EXOGENOUS AND ENDOGENOUS $\mathrm{H}_{2} \mathrm{O}_{2}$ SUPPRESS DA RELEASE}

The first criterion for classification of a substance as a neuromodulator is that the same response must be elicited by the exogenous and endogenous substance. Our initial studies of $\mathrm{H}_{2} \mathrm{O}_{2}$-dependent regulation of striatal DA release revealed that brief exposure of guinea-pig striatal slices to exogenous $\mathrm{H}_{2} \mathrm{O}_{2}$ (1.5 $\mathrm{mM}$ for $15 \mathrm{~min})$ suppresses $[\mathrm{DA}]_{\mathrm{o}}$, evoked by pulse-train stimulation (30-50 pulses at $10 \mathrm{~Hz}, 0.4-0.8 \mathrm{~mA}$ pulse amplitude) in the dorsal striatum ${ }^{20}$ (Figure 1A). This effect is not accompanied by a decrease in striatal DA content, indicating that it is not a consequence of loss of the releasable pool of DA. ${ }^{20}$ Moreover, the effect is reversible and occurs without causing lipid peroxidation, demonstrating that $\mathrm{H}_{2} \mathrm{O}_{2}$ exposure under these conditions does not cause oxidative damage. ${ }^{20}$ Subsequently, we found that elevation of endogenous $\mathrm{H}_{2} \mathrm{O}_{2}$ has a similar effect on the peak amplitude of evoked [DA $]_{\mathrm{o}}$. Amplification of endogenous $\mathrm{H}_{2} \mathrm{O}_{2}$ levels following inhibition of the $\mathrm{H}_{2} \mathrm{O}_{2}$-metabolizing enzyme glutathione (GSH) peroxidase with mercaptosuccinate (MCS) also causes a reversible decrease in pulse-train evoked $[\mathrm{DA}]_{0}^{21}$ (Figure $1 \mathrm{~B}$ ), which is also not accompanied by a change in DA content. ${ }^{22}$ Similar suppression of pulse-train evoked $[\mathrm{DA}]_{\mathrm{o}}$ by exogenous and endogenous $\mathrm{H}_{2} \mathrm{O}_{2}$ is also seen in the ventral striatum, including the nucleus accumbens (NAc) shell ${ }^{23}$ (Figure 1C). The inhibitory effect of MCS on evoked $[\mathrm{DA}]_{\mathrm{o}}$ persists when the DAT is inhibited, indicating that endogenous $\mathrm{H}_{2} \mathrm{O}_{2}$ decreases evoked $[\mathrm{DA}]_{\mathrm{o}}$ by inhibiting release rather than by enhancing DA uptake. ${ }^{21}$

It is important to emphasize, however, that DA release inhibition by endogenous $\mathrm{H}_{2} \mathrm{O}_{2}$ occurs under physiological conditions, that is, in the absence of GSH peroxidase inhibition. As discussed in the following sections, generation of inhibitory $\mathrm{H}_{2} \mathrm{O}_{2}$ occurs downstream from AMPAR activation in dorsal striatum during local pulse-train stimulation under control conditions. $^{21,22} \mathrm{~A}$ consequence of this is an increase in pulsetrain evoked $[\mathrm{DA}]_{\mathrm{o}}$ when AMPARs are blocked, indicating
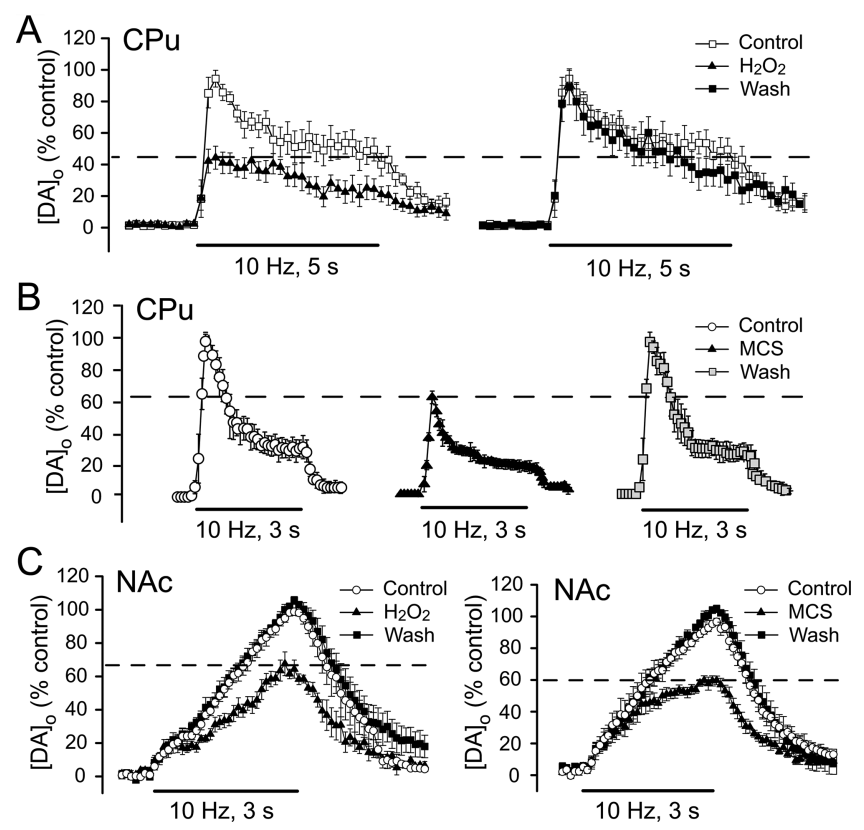

Figure 1. Both exogenous and endogenous $\mathrm{H}_{2} \mathrm{O}_{2}$ suppress striatal DA release. (A) Left: Exogenous $\mathrm{H}_{2} \mathrm{O}_{2}(1.5 \mathrm{mM}, 15 \mathrm{~min})$ inhibits pulsetrain evoked extracellular DA concentration $\left([\mathrm{DA}]_{\mathrm{o}}\right)$ in the dorsal striatum (caudate putamen, $\mathrm{CPu}$ ). Right: $\mathrm{DA}$ release-suppression is fully reversibly upon washout (wash). (B) Amplification of endogenous $\mathrm{H}_{2} \mathrm{O}_{2}$ levels by inhibition of the $\mathrm{H}_{2} \mathrm{O}_{2}$ metabolizing enzyme GSH peroxidase with mecaptosuccinate (MCS, $1 \mathrm{mM}$ ), also reversibly inhibits pulse-train evoked $[\mathrm{DA}]_{\mathrm{o}}$ in the $\mathrm{CPu}$. (C) Both exogenous $\mathrm{H}_{2} \mathrm{O}_{2}$ (left) and MCS (right) reversibly decrease evoked $[\mathrm{DA}]_{\mathrm{o}}$ in the nucleus accumbens (NAc) shell, demonstrating sensitivity of DA release regulation by $\mathrm{H}_{2} \mathrm{O}_{2}$ throughout the striatal complex. Data are means \pm SEM (A is modified from ref $20, B$ is modified from ref 21 , and $\mathrm{C}$ is modified from ref 23 ).

normal glutamatergic inhibition of DA release that is completely prevented in the presence of exogenous GSH peroxidase or catalase. ${ }^{21}$

Although exogenous $\mathrm{H}_{2} \mathrm{O}_{2}$ also suppresses [DA] evoked by a single stimulus pulse, inhibition of GSH peroxidase by MCS does not. ${ }^{21}$ This makes two points. First, basal levels of $\mathrm{H}_{2} \mathrm{O}_{2}$ in the striatum are insufficient to modulate axonal DA tonically release, even with amplification by GSH peroxidase inhibition; this contrasts with the more significant role of basal $\mathrm{H}_{2} \mathrm{O}_{2}$ levels in regulating the firing rate of $\mathrm{DA}$ neurons in the $\mathrm{SNc}^{24}$ The second point is that AMPAR-dependent modulatory $\mathrm{H}_{2} \mathrm{O}_{2}$ is generated dynamically during the first few pulses of a stimulus train, as seen in our $\mathrm{H}_{2} \mathrm{O}_{2}$ imaging studies (Figure $2 \mathrm{~B}$ ), with consequent, $\mathrm{H}_{2} \mathrm{O}_{2}$-dependent inhibition of DA released by subsequent pulses, even under control conditions. Overall, these findings demonstrate that endogenous $\mathrm{H}_{2} \mathrm{O}_{2}$ has a similar effect to that of exogenous $\mathrm{H}_{2} \mathrm{O}_{2}$ in suppressing axonal DA release in the striatum, thereby fulfilling the first criterion for classification as a neuromodulator.

\section{CRITERION 2: SYNTHESIS OF $\mathrm{H}_{2} \mathrm{O}_{2}$ IN STRIATAL MEDIUM SPINY NEURONS}

The second criterion that a neuromodulator must be synthesized in neurons is easily met by $\mathrm{H}_{2} \mathrm{O}_{2}$. Indeed, $\mathrm{H}_{2} \mathrm{O}_{2}$ is generated in all cells during mitochondrial respiration. ${ }^{25-27}$ This process generates $\mathrm{H}_{2} \mathrm{O}_{2}$ by mitochondrial electron transport; $\mathrm{O}_{2}$ is reduced to form the superoxide radical $\left({ }^{\bullet} \mathrm{O}_{2}{ }^{-}\right)$, which is then converted to $\mathrm{H}_{2} \mathrm{O}_{2}$ either through 


\section{A Respiratory}

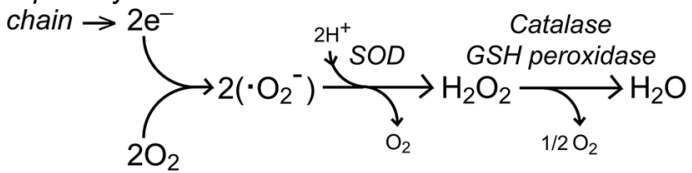
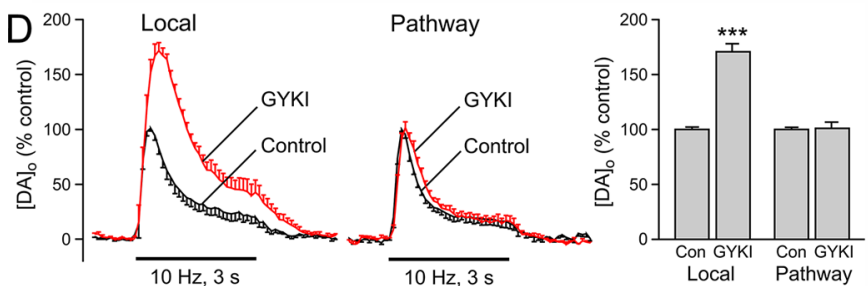
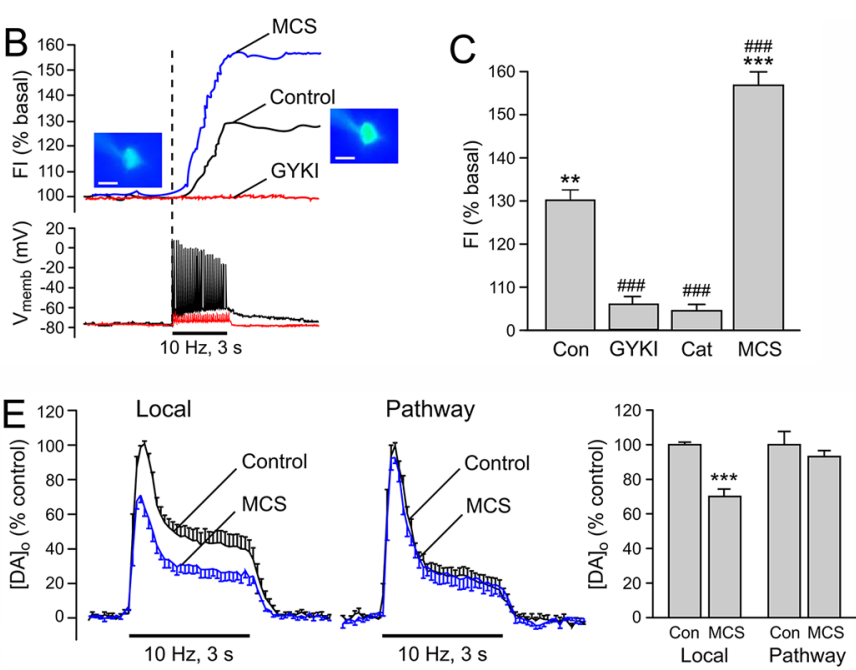

Figure 2. Synthesis and regulation of $\mathrm{H}_{2} \mathrm{O}_{2}$ in striatal medium spiny neurons, not DA axons. (A) Generation of $\mathrm{H}_{2} \mathrm{O}_{2}$ by the mitochondrial respiratory chain in which reduction of $\mathrm{O}_{2}$ forms the superoxide radical $\left({ }^{\bullet} \mathrm{O}_{2}^{-}\right)$, which then produces $\mathrm{H}_{2} \mathrm{O}_{2}$ either through catalysis by superoxide dismutase (SOD) or by spontaneous dismutation. The antioxidant enzymes catalase and GSH peroxidase metabolize $\mathrm{H}_{2} \mathrm{O}_{2}$ thereby regulating endogenous $\mathrm{H}_{2} \mathrm{O}_{2}$ levels. (B) Upper: Basal and activity-dependent $\mathrm{H}_{2} \mathrm{O}_{2}$ generation in a striatal MSN indicated by a $30 \%$ increase in DCF fluorescence intensity (FI) with local pulse-train stimulation (30 pulses, $10 \mathrm{~Hz}$ ) under control conditions (black trace). Lower: Simultaneous wholecell recording of membrane potential $\left(V_{\text {memb }}\right)$ shows that a single action potential is generated for each stimulus pulse within the pulse train. Blockade of AMPARs with GYKI-52466 (GYKI, $50 \mu$ M; red traces) prevents both stimulus-induced MSN firing and $\mathrm{H}_{2} \mathrm{O}_{2}$ generation. When $\mathrm{H}_{2} \mathrm{O}_{2}$ metabolism is compromised by inhibiting GSH peroxidase activity with MCS ( $1 \mathrm{mM}$; blue trace), stimulus-induced $\mathrm{H}_{2} \mathrm{O}_{2}$ is enhanced. (C) The average increase in stimulus-induced $\mathrm{H}_{2} \mathrm{O}_{2}$, indicated by DCF FI, is eliminated by GYKI and catalase, and doubled by MCS, demonstrating the $\mathrm{H}_{2} \mathrm{O}_{2}$ dependence of the DCF response and our ability to alter $\mathrm{H}_{2} \mathrm{O}_{2}$ levels in MSNs by manipulating peroxidase activity $(* * p<0.01$; $* * *<<0.001$ vs each respective basal DCF-FI, ${ }^{\# \# \# ~} p<0.001$ vs control DCF-FI). (D, E) Differential regulation by GYKI and MCS on striatal DA release evoked at a single site by alternating local stimulation and selective stimulation of DA pathways demonstrates that modulatory $\mathrm{H}_{2} \mathrm{O}_{2}$ is not generated by DA axons. (D) Blockade of AMPARs with GYKI $(50-100 \mu \mathrm{M})$ increases [DA] evoked by local pulse-train stimulation indicating that endogenous glutamate normally enhances DA release $(* * * p<0.001$ vs local control). By contrast, GYKI has no effect on [DA] evoked by selective DA pathway stimulation, thereby confirming the absence of local glutamate release with this stimulus paradigm. (E) Inhibition of GSH peroxidase by MCS (1 $\mathrm{mM}$ ) suppresses $[\mathrm{DA}]_{\mathrm{o}}$ evoked by local stimulation $(* * *<0.001$ vs local control) but has no effect on DA release evoked by pathway stimulation, demonstrating a lack of modulatory $\mathrm{H}_{2} \mathrm{O}_{2}$ generation by DA axons. Data are means \pm SEM (B-E are modified from ref 22 ).

catalysis by superoxide dismutase (SOD) or by spontaneous dismutation (Figure 2A). Other less ubiquitous subcellular sources of ${ }^{\circ} \mathrm{O}_{2}^{-}$, and thus $\mathrm{H}_{2} \mathrm{O}_{2}$ generation, include the enzymes monoamine oxidase (MAO) $)^{28,29}$ and $\mathrm{NADPH}$ oxidase $^{30-34}$ It has been reported that the amount of $\mathrm{H}_{2} \mathrm{O}_{2}$ produced by brain mitochondria can reach $5 \%$ of the total $\mathrm{O}_{2}$ metabolized. ${ }^{35}$

Absolute levels of $\mathrm{H}_{2} \mathrm{O}_{2}$ within a given cell depend on the dynamic balance between the rate of $\mathrm{H}_{2} \mathrm{O}_{2}$ production and the rate of $\mathrm{H}_{2} \mathrm{O}_{2}$ metabolism by antioxidant enzymes, as well as diffusion away from the site of generation. The main antioxidant enzymes that regulate cellular $\mathrm{H}_{2} \mathrm{O}_{2}$ levels are catalase, which is located in intracellular peroxisomes of neurons and glia, ${ }^{18,36,37}$ and GSH peroxidase, which is present in mitochondria and in the cytosol, especially in glia. ${ }^{38}$ These enzymes catalyze the decomposition of $\mathrm{H}_{2} \mathrm{O}_{2}$ to water and $\mathrm{O}_{2}$. $\mathrm{H}_{2} \mathrm{O}_{2}$ levels are also regulated, albeit to a lesser extent, by peroxiredoxins and cellular thiols. ${ }^{39-43}$

Given that striatal MSNs, which express AMPARs, constitute $>90 \%$ of striatal neurons and are a prime target of DA axons, we hypothesized that these cells could be an important source of modulatory $\mathrm{H}_{2} \mathrm{O}_{2}$. To visualize $\mathrm{H}_{2} \mathrm{O}_{2}$ generation in individual MSNs, we used real-time fluorescence imaging of $\mathrm{H}_{2} \mathrm{O}_{2}$ activated dichlorofluorescein (DCF), coupled with whole-cell recording for simultaneous monitoring of neuronal activation in guinea-pig striatal slices. Although DCF fluorescence imaging is not suitable for quantitative evaluation of absolute $\mathrm{H}_{2} \mathrm{O}_{2}$ concentration, this dye can be used to monitor relative differences in basal and stimulated levels of $\mathrm{H}_{2} \mathrm{O}_{2} \cdot{ }^{19,44}$ Despite the fact that MSNs are electrically silent in brain slices, basal DCF fluorescence is detected in all cells tested, presumably reflecting tonic $\mathrm{H}_{2} \mathrm{O}_{2}$ production through mitochondrial respiration required to maintain ion gradients. ${ }^{22}$ During local electrical stimulation of dorsal striatum in ex vivo brain slices, each pulse of a stimulus train (e.g., 30 pulses, $10 \mathrm{~Hz}$ ) elicits a single action potential in recorded MSNs (Figure 2B); these spikes are AMPAR-dependent, as discussed further below. This stimulus paradigm simultaneously produces a $\sim 30 \%$ increase in DCF fluorescence in a majority of $\mathrm{MSNs}^{22}$ (Figure 2B). The observations that stimulus-induced increases in DCF fluorescence are absent in the presence of the $\mathrm{H}_{2} \mathrm{O}_{2}$ scavenging enzyme catalase and are doubled when the $\mathrm{H}_{2} \mathrm{O}_{2}$ metabolizing enzyme GSH peroxidase is inhibited by MCS confirmed $\mathrm{H}_{2} \mathrm{O}_{2}$ detection $^{22}$ (Figure 2C). Thus, $\mathrm{H}_{2} \mathrm{O}_{2}$ is synthesized in striatal MSNs, with regulation of $\mathrm{H}_{2} \mathrm{O}_{2}$ levels by cellular peroxidases, thereby fulfilling the second criterion for classification as a neuromodulator.

DA Axons Are Not a Source of Modulatory $\mathrm{H}_{2} \mathrm{O}_{2}$. Because all cells are capable of producing $\mathrm{H}_{2} \mathrm{O}_{2}$, an additional source of $\mathrm{H}_{2} \mathrm{O}_{2}$ for DA modulation could be DA axons themselves. However, several observations prove that this is not the case. First, DA release modulation by endogenous $\mathrm{H}_{2} \mathrm{O}_{2}$ requires AMPAR activation; the effect of MCS on pulse-train evoked $[\mathrm{DA}]_{\mathrm{o}}$ is lost when AMPARs are blocked, indicating that there is no remaining $\mathrm{H}_{2} \mathrm{O}_{2}$ signal to amplify and thus the source of modulatory $\mathrm{H}_{2} \mathrm{O}_{2}$ is AMPAR-dependent. ${ }^{21}$ Second, 

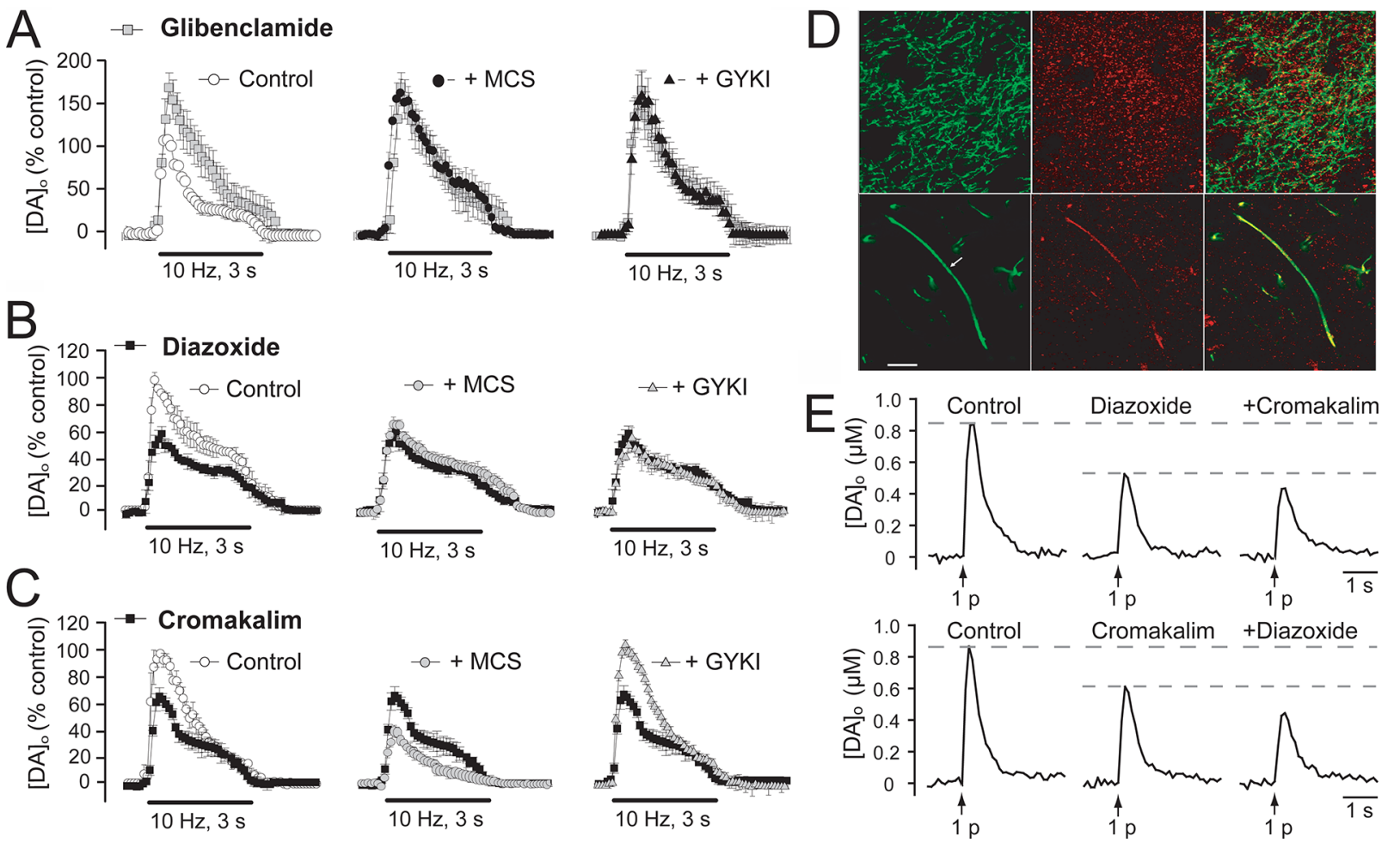

Figure 3. Endogenous $\mathrm{H}_{2} \mathrm{O}_{2}$ suppresses DA release via $\mathrm{K}_{\mathrm{ATP}}$ channels on DA axons. (A) The $\mathrm{K}_{\mathrm{ATP}}$-channel blocker, glibenclamide ( $\left.3 \mu \mathrm{M}\right)$, increases pulse-train evoked $[\mathrm{DA}]_{\mathrm{o}}$ in the dorsal striatum and prevents the usual suppression of DA release by the GSH peroxidase inhibitor MCS or enhancement of release by the AMPAR antagonist GYKI-52466 (GYKI). (B) The SUR1 subunit sensitive $\mathrm{K}_{\mathrm{ATP}}$-channel opener diazoxide (30 $\mu \mathrm{M}$ ) decreases pulse-train evoked $[D A]_{0}$ and prevents the usual effects of MCS and GYKI. (C) The SUR2 subunit sensitive $\mathrm{K}_{\mathrm{ATP}}$-channel opener cromakalim $(30 \mu \mathrm{M})$ also suppresses pulse-train evoked $[\mathrm{DA}]_{\mathrm{o}}$ but in contrast to diazoxide does not alter the effects of MCS and GYKI. (D) Immunohistochemical staining of striatum with an anti-tyrosine hydroxylase (TH) antibody for DA axons (green) and an anti-Kir6.2 antibody (red) for $\mathrm{K}_{\mathrm{ATP}}$ channels. The upper panel shows colocalization of $\mathrm{K}_{\mathrm{ATP}}$ channels in DA axons, as well as other cells and processes. The lower panel shows $\mathrm{K}_{\mathrm{ATP}}$-channel labeling along the length of an extended DA axon. (E) Independent suppression of single pulse evoked DA release by diazoxide and cromakalim suggest that both SUR1 and SUR2 $\mathrm{K}_{\mathrm{ATP}}$ channels are functionally present on DA axons. Data are means \pm SEM (A-C are modified from ref 63; $\mathrm{D}$ and $\mathrm{E}$ are modified from ref 70).

blockade of AMPARs with an antagonist, GYKI-52466, prevents $\mathrm{H}_{2} \mathrm{O}_{2}$ generation in MSNs during local pulse-train stimulation (Figure 2B), which leads to a 2 -fold increase in local pulse-train evoked [DA $]_{\mathrm{o}}$ (Figure 2D). Because DA axons in dorsal striatum lack AMPARs, ${ }^{45-47}$ it is unlikely that modulation of DA release by $\mathrm{H}_{2} \mathrm{O}_{2}$ is a self-regulatory process.

The third and most direct observation for lack of DA axon involvement comes from experiments using parasagittal slices; this preparation allows the use of distal stimulation of nigrostriatal DA axons to evoke DA release and thereby avoid the concurrent glutamate release that accompanies local stimulation. $^{22}$ The absence of local glutamate release was shown by the lack of effect of AMPAR antagonism by GYKI52466 on pathway-evoked $[\mathrm{DA}]_{\mathrm{o}}$, but the usual enhancement of locally evoked $[\mathrm{DA}]_{\mathrm{o}}$ at the same recording site (Figure 2D). We also found no increase in DCF fluorescence in MSNs or induction of MSN spiking with DA pathway stimulation; ${ }^{22}$ the absence of co-released glutamate from DA axons in dorsal striatum was later confirmed in optogenetic studies. ${ }^{48}$ Importantly, we found no evidence for an AMPAR-independent contribution from DA axons to the generation of modulatory $\mathrm{H}_{2} \mathrm{O}_{2}$ : inhibition of GSH peroxidase by MCS also has no effect on pathway-evoked DA release ${ }^{22}$ (Figure $2 \mathrm{E}$ ). Thus, these data not only show that DA axons are not the primary source of neuromodulatory $\mathrm{H}_{2} \mathrm{O}_{2}$, but also confirm that $\mathrm{H}_{2} \mathrm{O}_{2}$ is necessarily a diffusible messenger in the striatum.
What Subcellular Processes Generate Modulatory $\mathrm{H}_{2} \mathrm{O}_{2}$ ? As noted above, there are at least three subcellular sources of $\mathrm{H}_{2} \mathrm{O}_{2}$ : mitochondrial respiration; $\mathrm{MAO}$; and NADPH oxidase. We have shown that the usual effects of GSH peroxidase inhibition or AMPAR blockade on evoked $[\mathrm{DA}]_{\mathrm{o}}$ are completely lost in the presence of rotenone, a complex I inhibitor, and succinate, a mitochondrial complex II substrate, which together limit $\mathrm{H}_{2} \mathrm{O}_{2}$ production, but maintain tissue ATP content. ${ }^{49}$ These data implicate mitochondrial complex I as the primary source of rapid neuronal signaling by $\mathrm{H}_{2} \mathrm{O}_{2}$ in the striatum. Another source with particular relevance in monoaminergic regions is $\mathrm{MAO}$, which catalyzes deamination of DA and other biogenic amines via a two-electron reduction of $\mathrm{O}_{2}$ to $\mathrm{H}_{2} \mathrm{O}_{2}$, with one molecule of $\mathrm{H}_{2} \mathrm{O}_{2}$ produced for each molecule of DA metabolized. ${ }^{50,51}$ The isoforms of MAO are type A (MAO-A) and type B (MAO-B), with MAOA primarily in neurons and MAO-B primarily in glia. ${ }^{29,52}$ However, the ability of $\mathrm{H}_{2} \mathrm{O}_{2}$ amplification by MCS to suppress pulse-train evoked $[\mathrm{DA}]_{\mathrm{o}}$ is unaltered by a cocktail of MAO-A and MAO-B inhibitors, as is the effect of the AMPAR antagonist GYKI-52466. ${ }^{49} \mathrm{NADPH}$ oxidase belongs to a family of membrane-associated, multisubunit enzymes that catalyze the one-electron reduction of $\mathrm{O}_{2}$ to form ${ }^{\circ} \mathrm{O}_{2}{ }^{-}$and subsequently $\mathrm{H}_{2} \mathrm{O}_{2} \cdot{ }^{30-34}$ However, inhibition of $\mathrm{NADPH}$ oxidase by phenylarsine oxide also fails to prevent the effect of MCS or GYKI-5466 on evoked [DA $]_{0}{ }^{49}$ Thus, dynamic, 
glutamate-dependent modulation of striatal DA release requires $\mathrm{H}_{2} \mathrm{O}_{2}$ that originates from mitochondria, rather than MAO or $\mathrm{NADPH}$ oxidase. Of course, this does not exclude roles of $\mathrm{H}_{2} \mathrm{O}_{2}$ derived from MAO-dependent DA metabolism or $\mathrm{NADPH}$ oxidase in other aspects of neuronal regulation on longer time scales. ${ }^{18,32,53-56}$

\section{CRITERION 3: $\mathrm{H}_{2} \mathrm{O}_{2}$ GENERATION IN MSNS REQUIRES SYNAPTIC GLUTAMATERGIC DEPOLARIZATION}

Activity-dependent $\mathrm{H}_{2} \mathrm{O}_{2}$ generation in striatal MSNs not only implicates these neurons as a source of modulatory $\mathrm{H}_{2} \mathrm{O}_{2}$, but also implies that $\mathrm{H}_{2} \mathrm{O}_{2}$ is produced in response to neuronal activation, meeting the third criterion for classification as a neuromodulator. Indeed, stimulus-induced $\mathrm{H}_{2} \mathrm{O}_{2}$ generation in striatal MSNs does not occur when $\mathrm{Na}^{+}$channels are blocked by TTX. However, this process also requires glutamatergic activation of AMPARs on these neurons. Antagonism of AMPARs with GYKI-52466 during local electrical stimulation in dorsal striatum prevents generation of action potentials, as well as $\mathrm{H}_{2} \mathrm{O}_{2}$ elevation (Figure 2B). By contrast, neither of these parameters is altered by antagonism of NMDA receptors (NMDARs) under the same experimental conditions. ${ }^{22}$ Notably, we found no detectable $\mathrm{H}_{2} \mathrm{O}_{2}$ elevation when action potentials are generated in single MSNs by current injection pulses, implying that depolarization alone may not be sufficient to generate modulatory $\mathrm{H}_{2} \mathrm{O}_{2}$ in these cells. ${ }^{22}$ This result suggests a key role for glutamate in striatal $\mathrm{H}_{2} \mathrm{O}_{2}$ generation, and is consistent with previous studies in cultured cells showing glutamate-dependent increases in intracellular ROS production. ${ }^{26,57-60}$

How is $\mathrm{H}_{2} \mathrm{O}_{2}$ "released"? Once generated, $\mathrm{H}_{2} \mathrm{O}_{2}$ apparently quickly diffuses away from a site of generation; as a neutral molecule, it can be relatively membrane permeable, although recent studies suggest that it may escape the intracellular compartment via aquaporin channels. ${ }^{61,62}$ However, the fact that $\mathrm{H}_{2} \mathrm{O}_{2}$ generated in MSNs can inhibit DA release from striatal DA axons provides functional evidence that modulatory $\mathrm{H}_{2} \mathrm{O}_{2}$ is released from MSNs. Thus, $\mathrm{H}_{2} \mathrm{O}_{2}$ "release" in response to transmitter action and consequent depolarization addresses the third criteria for $\mathrm{H}_{2} \mathrm{O}_{2}$ as a striatal neuromodulator.

\section{CRITERION 4: ENDOGENOUS $\mathrm{H}_{2} \mathrm{O}_{2}$ SUPPRESSES DA RELEASE VIA $K_{\text {ATP }}$ CHANNELS ON DA AXONS}

The main targets of $\mathrm{H}_{2} \mathrm{O}_{2}$ for DA release regulation have been identified as $\mathrm{K}_{\text {ATP }}$ channels, ${ }^{63}$ which fulfills the fourth criterion for classification of $\mathrm{H}_{2} \mathrm{O}_{2}$ as a neuromodulator. Binding and immunohistochemical studies show that $\mathrm{K}_{\mathrm{ATP}}$ channels are highly expressed in the striatum. ${ }^{64-70}$ The role of $\mathrm{H}_{2} \mathrm{O}_{2}$ sensitive $\mathrm{K}_{\mathrm{ATP}}$ channels in axonal DA release regulation in dorsal striatum was first demonstrated by prevention of the usual changes in pulse-train evoked $[\mathrm{DA}]_{\mathrm{o}}$ with GSH peroxidase inhibition by MCS or AMPAR antagonism by GYKI-52466 in the presence of a $\mathrm{K}_{\mathrm{ATP}}$ channel blocker, like tolbutamide or glibenclamide ${ }^{21,63}$ (Figure 3A). These and other studies show that activity-dependent $\mathrm{H}_{2} \mathrm{O}_{2}$ causes $\mathrm{K}_{\mathrm{ATP}}$-channel opening, with elevation of $\mathrm{H}_{2} \mathrm{O}_{2}$ leading to $\mathrm{K}_{\mathrm{ATP}}$-channeldependent suppression of axonal DA release or DA neuron firing. $^{21,24,63}$

Many neuromodulators have receptors that are activated selectively, if not specifically, by a given modulatory agent; for example, the D1 and D2 family receptors are activated selectively by DA. However, $\mathrm{K}_{\mathrm{ATP}}$ channels have other known regulators besides $\mathrm{H}_{2} \mathrm{O}_{2}$, the most obvious of which are low ATP and/or elevated ADP; through these, $\mathrm{K}_{\mathrm{ATP}}$ channels act to couple the metabolic state of a cell to membrane excitability. ${ }^{71}$ Previous studies using inside-out membrane patches from cardiac cells have shown a direct, concentration-dependent effect of $\mathrm{H}_{2} \mathrm{O}_{2}$ on $\mathrm{K}_{\mathrm{ATP}}$-channel opening by decreasing channel sensitivity to ATP. ${ }^{72,73}$ However, whether $\mathrm{H}_{2} \mathrm{O}_{2}$ regulation of $\mathrm{K}_{\mathrm{ATP}}$ channels in intact DA neurons is direct or indirect has not yet been established. $K_{A T P}$ channels are octameric proteins ${ }^{74,75}$ composed of four inward rectifier $\mathrm{K}^{+}$channel subunits that form a central pore, typically Kir6.2 in neurons and Kir6.1 in glia, ${ }^{69,76-78}$ and four surrounding sulfonylurea-binding subunits, either SUR1 or SUR2. ${ }^{71,79,80}$ Channels based on SUR1 or SUR2 subunits can be distinguished by their differential sensitivity to $\mathrm{K}_{\mathrm{ATP}}$-channel openers. ${ }^{81,82}$ Both SUR1-acting diazoxide and SUR2-acting cromakalim decrease pulse-train evoked $[\mathrm{DA}]_{\mathrm{o}}$ by roughly $30 \%^{63}$ (Figure 3B,C). However, suppression of evoked $[\mathrm{DA}]_{\mathrm{o}}$ by MCS is occluded only by diazoxide and not cromakalim, indicating that SUR1-based $\mathrm{K}_{\mathrm{ATP}}$ channels are the primary target of neuromodulatory $\mathrm{H}_{2} \mathrm{O}_{2}{ }^{63}$ (Figure 3B,C).

Identification of $\mathrm{K}_{\mathrm{ATP}}$ channels as the targets through which $\mathrm{H}_{2} \mathrm{O}_{2}$ inhibits DA release fulfills the fourth criterion of having a "receptor" that mediates the action of a putative neuromodulator. However, the use of pulse-train stimulation alone cannot indicate the location at which these $\mathrm{H}_{2} \mathrm{O}_{2}$-sensitive $\mathrm{K}_{\text {ATP }}$ channels alter DA release; that is, whether responses are mediated by $\mathrm{K}_{\mathrm{ATP}}$ channels on $\mathrm{DA}$ axons or elsewhere in the striatal microcircuitry. The most straightforward explanation for rapid, reversible inhibition of striatal DA release by $\mathrm{H}_{2} \mathrm{O}_{2}$ is that $\mathrm{K}_{\mathrm{ATP}}$ channels are located directly on DA axons. We tested this hypothesis using immunohistochemical methods, which confirmed that at least $30 \%$ of $\mathrm{K}_{\mathrm{ATP}}$ channels containing the Kir6.2 subunit in dorsal striatum are expressed by DA axons ${ }^{70}$ (Figure 3D). Functional studies examining the effect of SUR-subunit selective openers on $[\mathrm{DA}]_{\mathrm{o}}$ evoked by single-pulse stimulation, that is not modulated by glutamate, GABA, or D2 autoreceptors, ${ }^{21,-86}$ show that either SUR1-sensitive diazoxide or SUR2-sensitive cromakalim can independently decrease DA release $^{70}$ (Figure 3E).

Although DA release elicited by a single pulse is independent from regulation by glutamate and $\mathrm{GABA},{ }^{21,86}$ acetylcholine (ACh) release from striatal cholinergic interneurons exerts a strong modulatory effect on single-pulse evoked release through nicotinic ACh receptors (nAChRs) on DA axons: when nAChRs are blocked, single pulse evoked $[\mathrm{DA}]_{\mathrm{o}}$ is suppressed, but the frequency-responsiveness of brief pulse trains is enhanced. ${ }^{87-90}$ Given that cholinergic interneurons also express SUR1-based $\mathrm{K}_{\mathrm{ATP}}$ channels that can hyperpolarize these cells, ${ }^{91}$ one could speculate that $\mathrm{H}_{2} \mathrm{O}_{2}$ regulation of DA release might occur indirectly by inhibiting $\mathrm{ACh}$ release. However, this is not the case. First, activation of $\mathrm{K}_{\mathrm{ATP}}$ channels by diazoxide suppresses DA release evoked by 5-pulse trains to a similar degree across all frequencies tested, with no change in the frequency-dependence of evoked $[\mathrm{DA}]_{\mathrm{o}} \cdot{ }^{70}$ Thus, activation of $\mathrm{K}_{\mathrm{ATP}}$ channels fails to recreate the dynamic pattern of striatal DA release with frequency that is characteristic of decreased ACh release. Second, the effect of MCS on evoked $[\mathrm{DA}]_{0}$ is unaltered when nAChRs are blocked by mecamylamine, indicating that inhibition of axonal DA release by endogenous $\mathrm{H}_{2} \mathrm{O}_{2}$ is also independent of $\mathrm{H}_{2} \mathrm{O}_{2}$ effects on cholinergic interneurons. $^{70}$ 
Together, these anatomical and functional observations confirm the presence of striatal "receptors" in the form of $\mathrm{K}_{\text {ATP }}$ channels for neuromodulatory $\mathrm{H}_{2} \mathrm{O}_{2}$. Moreover, they show that $\mathrm{H}_{2} \mathrm{O}_{2}$ regulates DA release by activation of $\mathrm{K}_{\mathrm{ATP}}$ channels directly on DA axons.

\section{CRITERION 5: THE ROLES OF DIFFUSION AND ENZYMATIC DEGRADATION IN TERMINATION OF $\mathrm{H}_{2} \mathrm{O}_{2}$ EFFECTS}

The final criterion for a substance being a neuromodulator is that there must be a mechanism for inactivation. As already noted, $\mathrm{H}_{2} \mathrm{O}_{2}$ is metabolized primarily by the antioxidant enzymes GSH peroxidase and catalase (Figure 2A); inhibition of GSH peroxidase leading to amplification of endogenous $\mathrm{H}_{2} \mathrm{O}_{2}$ levels in cells in which it is generated (e.g., MSNs) (Figure 2C), with subsequent enhancement of $\mathrm{H}_{2} \mathrm{O}_{2}$-dependent suppression of DA release (Figures 1B, 2E). However, our studies have also shown that exogenous application of GSH peroxidase or catalase completely prevents the increase in striatal DA release normally seen with the AMPAR antagonist GYKI-52466 ${ }^{21}$ (Figure 4A,B). Moreover, exogenous catalase
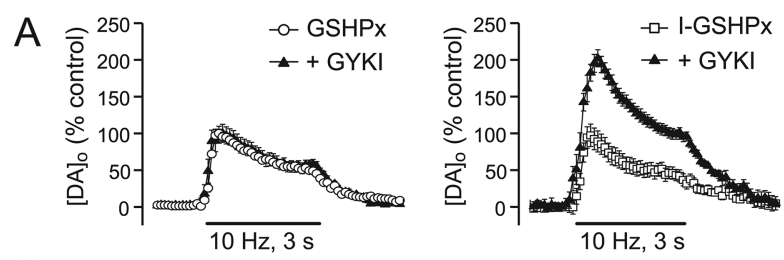

$\mathrm{B}$
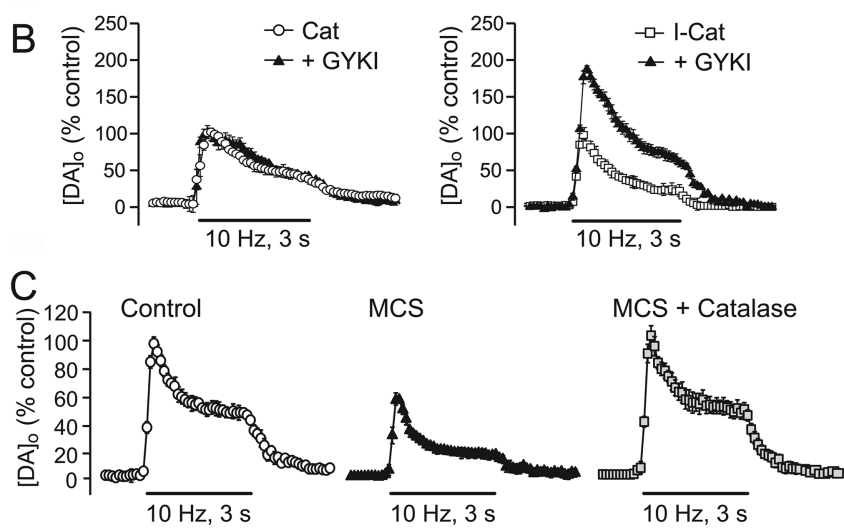

Figure 4. Enzymatic degradation in termination of $\mathrm{H}_{2} \mathrm{O}_{2}$ DA release regulation. (A, B) Exogenous application of the $\mathrm{H}_{2} \mathrm{O}_{2}$ metabolizing enzymes glutathione peroxidase (GSHPx) or catalase (Cat) completely prevents the increase in pulse-train evoked striatal [DA] normally seen with the AMPAR antagonist GYKI-52466 in dorsal striatum. By contrast, heat-inactivated forms of these enzymes (IGSHPx or I-Cat) are without effect. (C) Exogenous catalase also reverses the decrease in DA release usually seen when GSH peroxidase is inhibited with MCS. These data demonstrate the scavenging nature of these antioxidant enzymes in regulating and terminating the DA modulatory effects of endogenous $\mathrm{H}_{2} \mathrm{O}_{2}$. Data are means \pm SEM (modified from ref 21 ).

reverses the decrease in DA release usually seen when GSH peroxidase is inhibited with $\mathrm{MCS}^{21}$ (Figure 4C). These data not only demonstrate that the actions of endogenous $\mathrm{H}_{2} \mathrm{O}_{2}$ on striatal DA release are regulated by enzymatic degradation but they also confirm the role of $\mathrm{H}_{2} \mathrm{O}_{2}$ in glutamate-dependent regulation of DA release. Given the ability of $\mathrm{H}_{2} \mathrm{O}_{2}$ to cross plasma membranes, inactivation of dynamically generated $\mathrm{H}_{2} \mathrm{O}_{2}$ is likely to occur via diffusion and enzymatic inactivation in neighboring cells, as well as by regulation in the generating cell.

DA Release Suppression by Endogenous $\mathrm{H}_{2} \mathrm{O}_{2}$ and $\mathrm{K}_{\text {ATP }}$ Channels Is Rapid Yet Transient. What is the time frame for $\mathrm{H}_{2} \mathrm{O}_{2}$ induced suppression of DA release? Our studies of monitoring $\mathrm{H}_{2} \mathrm{O}_{2}$ in striatal MSNs with DCF suggest that $\mathrm{H}_{2} \mathrm{O}_{2}$ generation is rapid, occurring within a few hundred milliseconds following initiation of a $10 \mathrm{~Hz}$ stimulus burst ${ }^{22}$ (Figure 2B). In addition, suppression of pulse-train evoked $[\mathrm{DA}]_{\mathrm{o}}$ during GSH peroxidase inhibition or enhancement of pulse-train evoked $[\mathrm{DA}]_{\mathrm{o}}$ by AMPAR antagonism or $\mathrm{K}_{\mathrm{ATP}^{-}}$ channel blockade follows a similar time frame and is maintained throughout the stimulus. ${ }^{21,22,63}$ However, these observations provide little information about the dynamic window for $\mathrm{H}_{2} \mathrm{O}_{2}$ / $\mathrm{K}_{\mathrm{ATP}}$-channel-dependent modulation of striatal DA release.

We determined this regulatory time window using a paired pulse-paradigm in which the influence of endogenous $\mathrm{H}_{2} \mathrm{O}_{2}$ generated during an initial stimulus is assessed on $[\mathrm{DA}]_{\mathrm{o}}$ evoked by a subsequent test pulse applied at varying interpulse intervals $^{70}$ (Figure 5A). These studies revealed that when $\mathrm{K}_{\text {ATP }}$ channels are blocked by glibenclamide, DA release evoked by a subsequent test pulse at 500 or $1000 \mathrm{~ms}$ after the initial stimulus is enhanced, with loss of the effect by $1500 \mathrm{~ms}$. These data indicate a $1 \mathrm{~s}$ time window for $\mathrm{K}_{\mathrm{ATP}}$-channel activation and $\mathrm{DA}$ release inhibition after the stimulus ${ }^{70}$ (Figure 5A,B). The delay in onset of striatal DA release regulation by $\mathrm{H}_{2} \mathrm{O}_{2}$ at intervals of less than $500 \mathrm{~ms}$ could reflect a number of factors, including the time required for glutamate-AMPAR dependent $\mathrm{H}_{2} \mathrm{O}_{2}$ generation and diffusion of modulatory $\mathrm{H}_{2} \mathrm{O}_{2}$ from the site of generation (e.g., MSNs), to DA axons, ${ }^{22}$ as well as the time required for $\mathrm{K}_{\mathrm{ATP}}$-channel activation. In parallel experiments, we found that amplification of endogenous $\mathrm{H}_{2} \mathrm{O}_{2}$ levels by GSH peroxidase inhibition enhances DA release suppression at the same times that $\mathrm{K}_{\mathrm{ATP}}$-channel blockade led to enhanced evoked $[\mathrm{DA}]_{\mathrm{o}}$ after the initial stimulus ${ }^{70}$ (Figure $5 \mathrm{~B}$ ). This suggests that $\mathrm{H}_{2} \mathrm{O}_{2}$ metabolism, at least by GSH peroxidase, plays a greater role in regulating the amplitude of $\mathrm{H}_{2} \mathrm{O}_{2}$ signaling than in limiting its time course and, therefore, implicates diffusion and $\mathrm{K}_{\mathrm{ATP}}$-channel kinetics in the termination of action. Overall, these data show that the time window for $\mathrm{H}_{2} \mathrm{O}_{2} / \mathrm{K}_{\mathrm{ATP}}$-channel-dependent suppression of DA release is 500-1000 ms after a burst of activity.

\section{$\mathrm{H}_{2} \mathrm{O}_{2}$ MEDIATES DA RELEASE REGULATION BY GLUTAMATE, GABA, AND CANNABINOIDS}

Glutamate. Given the close apposition of dopaminergic and glutamatergic inputs on MSN spines, ${ }^{2,3}$ it is not surprising that glutamate regulates striatal DA release. However, the mechanism by which glutamate regulates DA release has been controversial. This may be in part due to the use of glutamate agonists that can induce widespread depolarization, including pathophysiological spreading depression. ${ }^{92,93}$ Glutamatergic transmission is generally regarded as being "hard-wired", with spillover limited by avid uptake. ${ }^{94-97}$ When glutamate spillover does occur, for example, when uptake is compromised, DA release is inhibited via metabotropic glutamate receptors on DA axons. ${ }^{98}$ However, because DA axons in the dorsal striatum lack both AMPARs and NMDARs, ${ }^{45-47}$ any effect of glutamate on DA release via these ionotropic receptors must be indirect. Our studies have revealed that glutamatergic activation of AMPARs inhibits striatal DA via $\mathrm{H}_{2} \mathrm{O}_{2}$ and $\mathrm{K}_{\text {ATP }}$ channels on DA axons, as outlined above. Glutamatergic excitation increases $\mathrm{H}_{2} \mathrm{O}_{2}$ generation in a large population of striatal MSNs via activation 


\section{A Control}
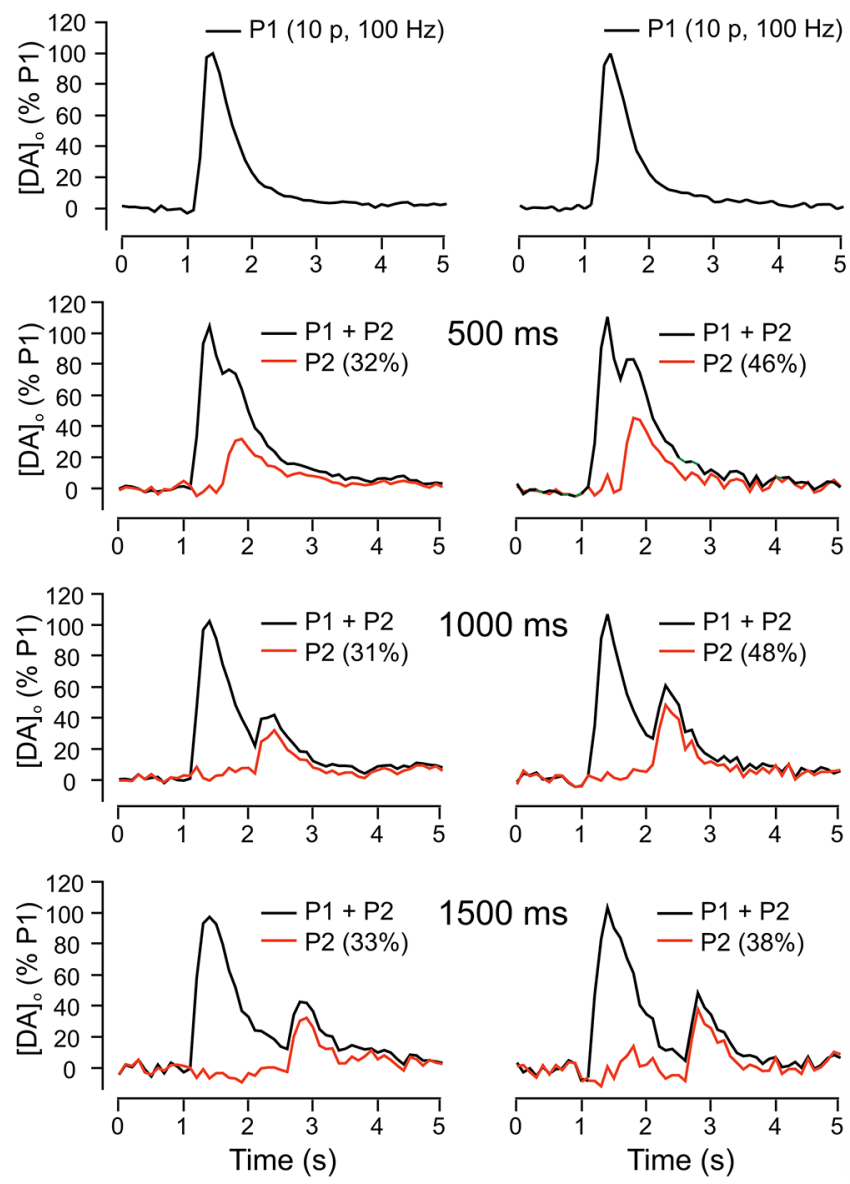

B
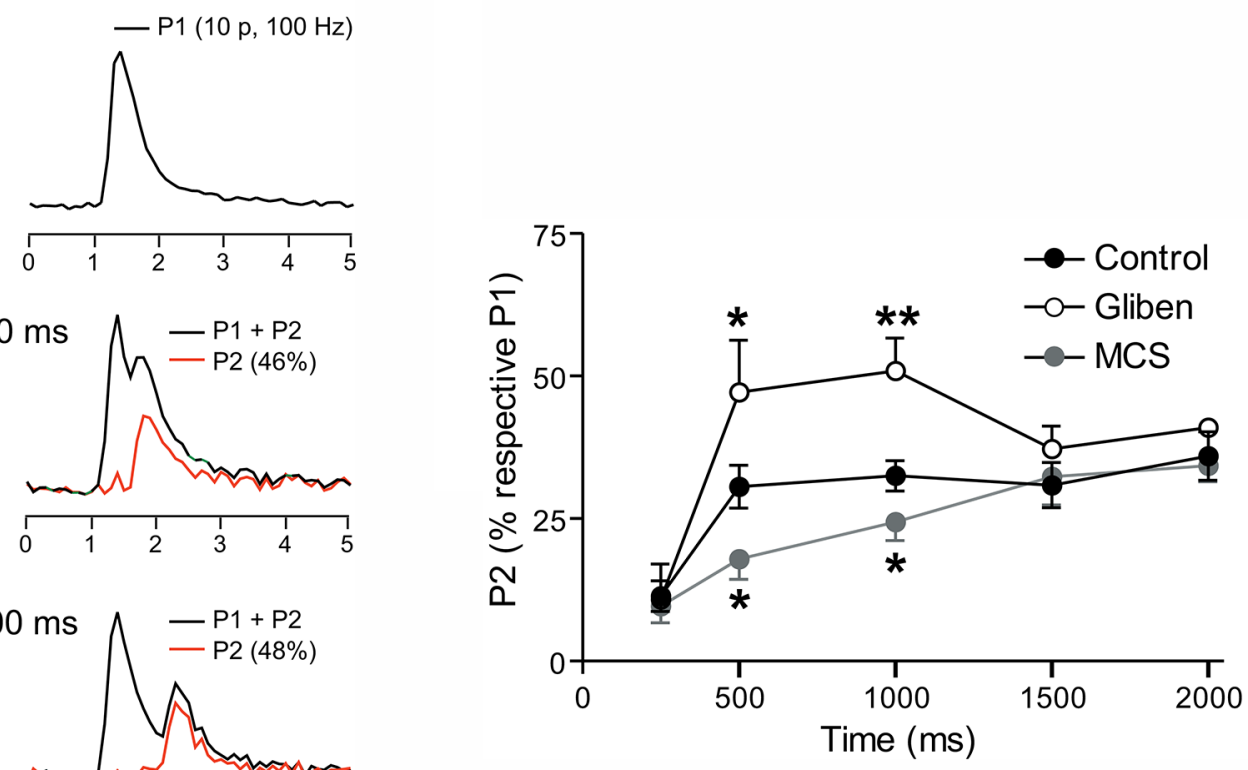

Figure 5. Time course of DA release suppression by endogenous $\mathrm{H}_{2} \mathrm{O}_{2}$ and $\mathrm{K}_{\mathrm{ATP}}$ channels. (A) Representative [DA $]_{\mathrm{o}}$ versus time records from the dorsal striatum using a paired-pulse stimulation paradigm in which a pseudo-one pulse stimulus (10 pulses, $100 \mathrm{~Hz}$; P1) is followed by a single test pulse (P2) at varying time intervals (P1 + P2, black traces), with subtracted P1 (red traces). Note the recovery of P2 amplitude with time in the absence and presence of the $\mathrm{K}_{\mathrm{ATP}}$-channel blocker glibenclamide $(3 \mu \mathrm{M})$. (B) Mean data showing the recovery in amplitude of [DA] relative to P1 under control conditions, in the presence of glibenclamide (Gliben) or in MCS, a GSH peroxidase inhibitor. Glibenclamide significantly increased $[\mathrm{DA}]_{\mathrm{o}}$ evoked by $\mathrm{P} 2$ at 500 and $1000 \mathrm{~ms}$, whereas MCS significantly decreased P2 at these time points, thereby revealing a role for endogenous $\mathrm{H}_{2} \mathrm{O}_{2}$ generation by P1 stimulation in DA release suppression; P2 values returned to control levels by $1500 \mathrm{~ms}(* p<0.05$; ** $p<0.01$ vs control). These data indicate rapid yet transient suppression of axonal DA release by endogenous $\mathrm{H}_{2} \mathrm{O}_{2}$ and $\mathrm{K}_{\mathrm{ATP}}$ channels. Data are means \pm SEM (modified from ref 70).

of AMPARs. When AMPARs are blocked in dorsal striatum, dynamic $\mathrm{H}_{2} \mathrm{O}_{2}$ generation in MSNs is prevented, leading to an increase in pulse-train evoked DA release ${ }^{21,22}$ (Figure 2B,C). Blocking NMDARs under the same conditions has no effect on $\mathrm{H}_{2} \mathrm{O}_{2}$ generation in MSNs or evoked $[\mathrm{DA}]_{\mathrm{o}}{ }^{21,22}$ The observations that the effect of GYKI-52466 is absent when the $\mathrm{H}_{2} \mathrm{O}_{2}$ scavenging enzymes catalase and $\mathrm{GSH}$ peroxidase are present $^{21}$ (Figure 4A,B), when mitochondrial $\mathrm{H}_{2} \mathrm{O}_{2}$ generation is prevented, ${ }^{49}$ or when $\mathrm{H}_{2} \mathrm{O}_{2}$-sensitive $\mathrm{K}_{\mathrm{ATP}}$ channels are blocked (Figure 3A) confirm that glutamatergic AMPARmodulation of DA release occurs exclusively through mitochondrial $\mathrm{H}_{2} \mathrm{O}_{2}$ and $\mathrm{K}_{\mathrm{ATP}}$-channel activation.

GABA. Regulation of axonal DA release in dorsal striatum by $\mathrm{GABA}$ is also unconventional. Blockade of $\mathrm{GABA}_{\mathrm{A}}$ receptors $\left(\mathrm{GABA}_{\mathrm{A}} \mathrm{Rs}\right)$ with picrotoxin causes a roughly $50 \%$ decrease in pulse-train evoked $[\mathrm{DA}]_{\mathrm{o}}$ in the dorsal striatum, showing that GABA enhances DA release whereas blockade of $G_{A B A} R$ s is without effect. ${ }^{21}$ The influence of GABA on DA release, like that of glutamate, must be indirect, because DA axons in dorsal striatum do not appear to express ionotropic GABARs. ${ }^{99}$ Our studies have revealed that GABAergic modulation of DA release also occurs via $\mathrm{H}_{2} \mathrm{O}_{2}$, with complete prevention of the effect of $\mathrm{GABA}_{\mathrm{A}} \mathrm{R}$ blockade by catalase ${ }^{21}$ and by the $\mathrm{K}_{\mathrm{ATP}}$-channel blocker glibenclamide. ${ }^{63}$ Moreover, picrotoxin has no effect when AMPARs are blocked, ${ }^{21}$ indicating that the actions of GABA at $\mathrm{GABA}_{\mathrm{A}}$ Rs must be mediated by the pool of $\mathrm{H}_{2} \mathrm{O}_{2}$ generated downstream from glutamate acting at AMPARs. The localization of $\mathrm{GABA}_{\mathrm{A}} \mathrm{Rs}$ near spines on the dendrites of $\mathrm{MSNs}^{99}$ provides ideal placement for the established role of GABA in attenuating glutamatergic excitation of MSNs, as well as for attenuation of glutamate-dependent $\mathrm{H}_{2} \mathrm{O}_{2}$ generation and DA release suppression.

Glutamate input to MSNs generates modulatory $\mathrm{H}_{2} \mathrm{O}_{2}$ that diffuses to adjacent DA axons, opens SUR1-based $\mathrm{K}_{\text {ATP }}$ channels that hyperpolarize DA axons, and thereby inhibits DA release. GABAergic activation of $\mathrm{GABA}_{\mathrm{A}} \mathrm{Rs}$ curtails AMPAR-dependent MSN excitation and consequent $\mathrm{H}_{2} \mathrm{O}_{2}$ generation from mitochondria. ${ }^{19}$ In the absence of glutamatergic input, or when AMPARs are blocked, $\mathrm{H}_{2} \mathrm{O}_{2}$ generation is minimized, $\mathrm{GABA}_{\mathrm{A}} \mathrm{R}$-dependent regulation is lost, and $\mathrm{DA}$ release is no longer inhibited by $\mathrm{H}_{2} \mathrm{O}_{2}$ acting at $\mathrm{K}_{\text {ATP }}$ channels. 
Thus, GABA has no direct influence on DA release when MSNs are not activated by glutamate.

Cannabinoids. Given the critical role that $\mathrm{H}_{2} \mathrm{O}_{2}$ plays in enabling the effects of glutamate and GABA on DA transmission in the dorsal striatum, it is not surprising to find that $\mathrm{H}_{2} \mathrm{O}_{2}$ is also involved in mediating the effect of other modulators on DA release that act by altering either glutamate or GABA transmission. One example is the regulation of DA release by cannabinoid activation of $\mathrm{CB} 1$ receptors (CB1Rs). Consistent with in vivo studies, pulse-train evoked $[\mathrm{DA}]_{\mathrm{o}}$ in the dorsal striatum in striatal slices is not altered by CB1R antagonists, indicating the absence of DA release regulation by endocannabinoids with brief, mild stimulation. However, CB1R agonists cause a decrease in pulse-train evoked $[\mathrm{DA}]_{\mathrm{o}}$ whereas single-pulse evoked $[\mathrm{DA}]_{\mathrm{o}}$ is unaffected, which implicates the involvement of local striatal circuitry in consequences of CB1R activation on DA release, rather than direct effects on DA axons. ${ }^{100,101}$ The effect of CB1R activation on pulse-train evoked $[\mathrm{DA}]_{\mathrm{o}}$ is prevented by $\mathrm{GABA}_{\mathrm{A}} \mathrm{R}$ blockade, by catalase, and by blockade of $K_{A T P}$ channels. ${ }^{101}$ Thus, these data implicate presynaptic inhibition of GABA release via presynaptic CB1Rs, with consequent increase in $\mathrm{MSN}$ activation and $\mathrm{H}_{2} \mathrm{O}_{2}$ generation. Consistent with this notion, the effect of the CB1R agonist WIN55,212-2 in dorsal striatum is also lost with AMPAR antagonism (Sidló and Rice, unpublished). Local inhibition of DA release consequent to GABA release inhibition might explain CB1R-agonist induced catalepsy, despite evidence for increased phasic DA-neuron activity. ${ }^{102}$

\section{CONCLUDING REMARKS}

The mechanistic studies reviewed here demonstrate that $\mathrm{H}_{2} \mathrm{O}_{2}$ meets the criteria for classification as a neuromodulator: both exogenous and endogenous $\mathrm{H}_{2} \mathrm{O}_{2}$ suppress DA release; endogenous $\mathrm{H}_{2} \mathrm{O}_{2}$ is generated by mitochondria in striatal MSNs in a manner that requires glutamatergic depolarization via AMPARs; dynamically generated $\mathrm{H}_{2} \mathrm{O}_{2}$ leaves the cell of generation and diffuses through the extracellular compartment to activate $\mathrm{K}_{\mathrm{ATP}}$ channels located directly on DA axons, thereby inhibiting exocytotic DA release; finally, the action of modulatory $\mathrm{H}_{2} \mathrm{O}_{2}$ is regulated by the metabolizing enzymes GSH peroxidase and catalase. Notably, findings from the dorsal striatum indicate that regulation of axonal DA release by glutamate and GABA acting via ionotropic receptors in that region occurs exclusively through modulatory $\mathrm{H}_{2} \mathrm{O}_{2}$. As a result, other on-demand modulators such as the cannabinoids that can alter glutamate or GABA transmission also rely on $\mathrm{H}_{2} \mathrm{O}_{2}$ to deliver the final message to DA axons.

Although the evidence summarized here is focused on $\mathrm{H}_{2} \mathrm{O}_{2}$ dependent modulation of axonal DA release in the striatum, the ubiquitous presence of mitochondria as sources of $\mathrm{H}_{2} \mathrm{O}_{2}$ in all cells and the widespread distribution of $\mathrm{K}_{\mathrm{ATP}}$ channels throughout the $\mathrm{CNS}^{64-70,76,89,90,103}$ imply that neuromodulation by $\mathrm{H}_{2} \mathrm{O}_{2}$ could be equally widespread. Indeed, endogenous $\mathrm{H}_{2} \mathrm{O}_{2}$ acts via $\mathrm{K}_{\text {ATP }}$ channels to regulate the activity of SNc DA neurons, ${ }^{24}$ striatal GABAergic MSNs ${ }^{104}$ and substantia nigra pars reticulata GABAergic neurons. ${ }^{105,106}$ In this light, it is possible that $\mathrm{H}_{2} \mathrm{O}_{2}$-dependent modulation could occur in other $\mathrm{K}_{\mathrm{ATP}}$-channel expressing cells elsewhere in the body, including pancreatic $\beta$-cells and cardiac myocytes. ${ }^{71-73,107,108}$

Lastly, it should be noted that $\mathrm{K}_{\mathrm{ATP}}$-channels are not the only ion-channel target of endogenous $\mathrm{H}_{2} \mathrm{O}_{2}$. Among the most intriguing of these is a subtype of transient receptor potential (TRP) channels, the TRP melastatin 2 (TRPM2) channel, which is uniquely sensitive to activation by $\mathrm{H}_{2} \mathrm{O}_{2} \cdot{ }^{109,110}$ In contrast to $\mathrm{K}_{\mathrm{ATP}}$ channels, which hyperpolarize neuronal membranes and decrease cell excitability, TRP channels are nonselective cation channels that cause membrane depolarization. In guinea-pig striatal MSNs and $\mathrm{SNr}$ GABAergic neurons, the primary effect of elevation of endogenous $\mathrm{H}_{2} \mathrm{O}_{2}$ is TRPchannel mediated depolarization and increased activity. ${ }^{104-106}$ The specific channel subtype underlying these effects in $\mathrm{SNr}$ neurons has been identified as TRPM2. ${ }^{106}$ Although $\mathrm{SNr}$ GABAergic neurons also express $\mathrm{K}_{\mathrm{ATP}}$ channels, the predominant effect of $\mathrm{H}_{2} \mathrm{O}_{2}$ elevation on these cells in guinea-pig $\mathrm{SNr}$ (albeit not in mouse $\mathrm{SNr}$ ) is depolarization and increased firing rate. ${ }^{105}$ In contrast, although DA neurons in guinea-pig SNc express TRPM2, ${ }^{106}$ as well as $\mathrm{K}_{\mathrm{ATP}}$ channels, the predominant effect of $\mathrm{H}_{2} \mathrm{O}_{2}$ elevation on $\mathrm{SNc}$ neurons is hyperpolarization. ${ }^{24}$ These data indicate that the net effect of $\mathrm{H}_{2} \mathrm{O}_{2}$ on a given cell or transmitter release site will reflect the balance between $\mathrm{H}_{2} \mathrm{O}_{2}$-sensitive target channels expressed and thereby provide cell-type-specific patterns of modulation.

\section{AUTHOR INFORMATION}

\section{Corresponding Author}

*Telephone: 212-263-5177. Fax: 212-689-0334. E-mail: jyotiben.patel@nyumc.org.

\section{Author Contributions}

Both authors contributed to the writing of this review and to the preparation of the figures.

\section{Funding}

This work was supported by NIH/NINDS grant NS036362 and the Olympia and Attilio Ricciardi Research Fund.

\section{Notes}

The authors declare no competing financial interest.

\section{ACKNOWLEDGMENTS}

We would like to thank past and present members of the Rice Laboratory for their contributions to the original studies reviewed in this article.

\section{REFERENCES}

(1) Dahlström, A., and Fuxe, K. (1964) Evidence of the existence of monoamine-containing neurons in the central nervous system. I: Demonstration of monoamines in the cell bodies of brain stem neurons. Acta. Physiol. Scand. 62, 1-55.

(2) Freund, T. F., Powell, J. F., and Smith, A. D. (1984) Tyrosine hydroxylase-immunoreactive boutons in synaptic contact with identified striatonigral neurons, with particular reference to dendritic spines. Neuroscience 13, 1189-1215.

(3) Smith, A. D., and Bolam, J. P. (1990) The neural artwork of the basal ganglia as revealed by the study of synaptic connections of identified neurons. Trends Neurosci. 13, 259-265.

(4) Surmeier, D. J., Carrillo-Reid, L., and Bargas, J. (2011) Dopaminergic modulation of striatal neurons, circuits, and assemblies. Neuroscience 198, 3-18.

(5) Cagniard, B., Beeler, J. A., Britt, J. P., McGehee, D. S., Marinelli, M., and Zhuang, X. (2006) Dopamine scales performance in the absence of new learning. Neuron 51, 541-547.

(6) Gerfen, C. R, and Surmeier, D. J. (2011) Modulation of striatal projection systems by dopamine. Annu. Rev. Neurosci. 34, 441-466.

(7) Yung, K. K., Bolam, J. P., Smith, A. D., Hersch, S. M., Ciliax, B. J., and Levey, A. I. (1995) Immunocytochemical localization of D1 and D2 dopamine receptors in the basal ganglia of the rat: light and electron microscopy. Neuroscience 65, 709-730.

(8) Cragg, S. J., and Rice, M. E. (2004) DAncing past the DAT at a DA synapse. Trends Neurosci. 27, 270-277. 
(9) Rice, M. E., and Cragg, S. J. (2008) Dopamine spillover after quantal release: rethinking dopamine transmission in the nigrostriatal pathway. Brain Res. Rev. 58, 303-313.

(10) Rice, M. E., Patel, J. C., and Cragg, S. J. (2011) Dopamine release in the basal ganglia. Neuroscience 198, 112-137.

(11) Carlsson, A. (2002) Treatment of Parkinson's with L-DOPA. The early discovery phase, and a comment on current problems. J. Neural Transm. 109, 777-787.

(12) Mallet, N., Pogosyan, A., Sharott, A., Csicsvari, J., Bolam, J. P., Brown, P., and Magill, P. J. (2008) Disrupted dopamine transmission and the emergence of exaggerated beta oscillations in subthalamic nucleus and cerebral cortex. J. Neurosci. 28, 4795-4806.

(13) Wichmann, T., and Dostrovsky, J. O. (2011) Pathological basal ganglia activity in movement disorders. Neuroscience 198, 232-244.

(14) Millar, J., Stamford, J. A., Kruk, Z. L., and Wightman, R. M. (1985) Electrochemical, pharmacological and electrophysiological evidence of rapid dopamine release and removal in the rat caudate nucleus following electrical stimulation of the median forebrain bundle. Eur. J. Pharmacol. 109, 341-348.

(15) Bull, D. R., Palij, P., Sheehan, M. J., Millar, J., Stamford, J. A., Kruk, Z. L., and Humphrey, P. P. (1990) Application of fast cyclic voltammetry to measurement of electrically evoked dopamine overflow from brain slices in vitro. J. Neurosci. Methods 32, 37-44.

(16) Patel, J. C., and Rice, M. E. (2006) Monitoring dopamine release in brain slices. In Encyclopedia of Sensors, Vol. 6 (Grimes, C. A., Dickey, E. C., Pishko, M. V., Eds.), pp 313-334, American Scientific Publishers, Stevenson Ranch, CA.

(17) Wightman, R. M. (2006) Detection technologies. Probing cellular chemistry in biological systems with microelectrodes. Science 311, 1570-1574.

(18) Cohen, G. (1994) Enzymatic/nonenzymatic sources of oxyradicals and regulation of antioxidant defenses. Ann. N.Y. Acad. Sci. 73, 8-14.

(19) Rice, M. E. (2011) $\mathrm{H}_{2} \mathrm{O}_{2}$ : a dynamic neuromodulator. The Neuroscientist 17, 389-406.

(20) Chen, B. T., Avshalumov, M. V., and Rice, M. E. (2001) $\mathrm{H}_{2} \mathrm{O}_{2}$ is a novel, endogenous modulator of synaptic dopamine release. $J$. Neurophysiol. 85, 2468-2476.

(21) Avshalumov, M. V., Chen, B. T., Marshall, S. P., Peña, D. M., and Rice, M. E. (2003) Glutamate-dependent inhibition of dopamine release in striatum is mediated by a new diffusible messenger, $\mathrm{H}_{2} \mathrm{O}_{2}$. J. Neurosci. 23, 2744-2750.

(22) Avshalumov, M. V., Patel, J. C., and Rice, M. E. (2008) AMPA receptor-dependent $\mathrm{H}_{2} \mathrm{O}_{2}$ generation in striatal medium spiny neurons, but not dopamine axons: one source of a retrograde signal that can inhibit dopamine release. J. Neurophysiol. 100, 1590-1601.

(23) Chen, B. T., Avshalumov, M. V., and Rice, M. E. (2002) Modulation of somatodendritic dopamine release by endogenous $\mathrm{H}_{2} \mathrm{O}_{2}$ : susceptibility in substantia nigra but resistance in VTA. J. Neurophysiol. 87, 1155-1158.

(24) Avshalumov, M. V., Chen, B. T., Koós, T., Tepper, J. M., and Rice, M. E. (2005) Endogenous hydrogen peroxide regulates the excitability of midbrain dopamine neurons via ATP-sensitive potassium channels. J. Neurosci. 25, 4222-4231.

(25) Boveris, A., and Chance, B. (1973) The mitochondrial generation of hydrogen peroxide. General properties and effect of hyperbaric oxygen. Biochem. J. 134, 707-716.

(26) Dugan, L. L., Sensi, S. L., Canzoniero, L. M., Handran, S. D., Rothman, S. M., Lin, T. S., Goldberg, M. P., and Choi, D. W. (1995) Mitochondrial production of reactive oxygen species in cortical neurons following exposure to N-methyl-D-aspartate. J. Neurosci. 15, 6377-6388.

(27) Liu, Y., Fiskum, G., and Schubert, D. (2002) Generation of reactive oxygen species by the mitochondrial electron transport chain. J. Neurochem. 80, 780-787.

(28) Maker, H. S., Weiss, C., Silides, D. J., and Cohen, G. (1981) Coupling of dopamine oxidation (monoamine oxidase activity) to glutathione oxidation via the generation of hydrogen peroxide in rat brain homogenates. J. Neurochem. 36, 589-593.
(29) Azzaro, A. J., King, J., Kotzuk, J., Schoepp, D. D., Frost, J., and Schochet, S. (1985) Guinea pig striatum as a model of human dopamine deamination: the role of monoamine oxidase isozyme ratio, localization, and affinity for substrate in synaptic dopamine metabolism. J. Neurochem. 45, 949-956.

(30) Babior, B. M. (1984) Oxidants from phagocytes: agents of defense and destruction. Blood 64, 959-966.

(31) Lambeth, J. D. (2004) NOX enzymes and the biology of reactive oxygen. Nat. Rev. Immunol. 4, 181-189.

(32) Infanger, D. W., Sharma, R. V., and Davisson, R. L. (2006) NADPH oxidases of the brain: distribution, regulation, and function. Antioxid. Redox Signal. 8, 1583-1596.

(33) Rhee, S. G. (2006) $\mathrm{H}_{2} \mathrm{O}_{2}$, a necessary evil for cell signaling. Science 312, 1882-1883.

(34) Bedard, K., and Krause, K. H. (2007) The NOX family of ROSgenerating NADPH oxidases: physiology and pathophysiology. Physiol. Rev. 87, 245-313.

(35) Arnaiz, S. L., Coronel, M. F., and Boveris, A. (1999) Nitric oxide, superoxide, and hydrogen peroxide production in brain mitochondria after haloperidol treatment. Nitric Oxide 3, 235-243.

(36) Peuchen, S., Bolanos, J. P., Heales, S. J., Almeida, A., Duchen, M. R. and Clark, J. B. (1997) Interrelationships between astrocyte function, oxidative stress and antioxidant status within the central nervous system. Prog. Neurobiol. 52, 261-281.

(37) Dringen, R., Pawlowski, P. G., and Hirrlinger, J. (2005) Peroxide detoxification by brain cells. J. Neurosci. Res. 79, 157-165.

(38) Stults, F. H., Forstrom, J. W., Chiu, D. T. Y., and Tappel, A. L. (1977) Rat liver glutathione peroxidase: purification and study of multiple forms. Arch. Biochem. Biophys. 183, 490-497.

(39) Rhee, S. G., Kang, S. W., Chang, T. S., Jeong, W., and Kim, K. (2001) Peroxiredoxins: a novel family of peroxidases. IUBMB Life 52, $35-41$.

(40) Rhee, S. G., Kang, S. W., Jeong, W., Chang, T. S., Yang, K. S., and Woo., H. A. (2005) Intracellular messenger function of hydrogen peroxide and its regulation by peroxiredoxins. Curr. Opin. Cell Biol. 17, 183-189.

(41) Hofmann, B., Hecht, H. J., and Flohe, L. (2002) Peroxiredoxins. Biol. Chem. 383, 347-364.

(42) Adimora, N. J., Jones, D. P., and Kemp, M. L. (2010) A model of redox kinetics implicates the thiol proteome in cellular hydrogen peroxide responses. Antioxid. Redox Signaling 13, 731-743.

(43) Mishina, N. M., Tyurin-Kuzmin, P. A., Markvicheva, K. N., Vorotnikov, A. V., Tkachuk, V. A., Laketa, V., Schultz, C., Lukyanov, S., and Belousov, V. V. (2011) Does cellular hydrogen peroxide diffuse or act locally? Antioxid. Redox Signaling 14, 1-7.

(44) Avshalumov, M. V., Bao, L., Patel, J. C., and Rice, M. E. (2007) $\mathrm{H}_{2} \mathrm{O}_{2}$ signaling in the nigrostriatal dopamine pathway via ATPsensitive potassium channels: issues and answers. Antioxid. Redox Signaling 9, 219-231.

(45) Bernard, V., and Bolam., J. P. (1998) Subcellular and subsynaptic distribution of the NR1 subunit of the NMDA receptor in the neostriatum and globus pallidus of the rat: colocalization at synapses with the GluR2/3 subunit of the AMPA receptor. Eur. J. Neurosci. 10, 3721-3738.

(46) Bernard, V., Somogyi, P., and Bolam, J. P. (1997) Cellular, subcellular, and subsynaptic distribution of AMPA-type glutamate receptor subunits in the neostriatum of the rat. J. Neurosci. 17, 819833.

(47) Chen, Q., Veenman, L., Knopp, K., Yan, Z., Medina, L., Song, W. J., Surmeier, D. J., and Reiner, A. (1998) Evidence for the preferential localization of glutamate receptor-1 subunits of AMPA receptors to the dendritic spines of medium spiny neurons in rat striatum. Neuroscience 83, 749-761.

(48) Stuber, G. D., Hnasko, T. S., Britt, J. P., Edwards, R. H., and Bonci, A. (2010) Dopaminergic terminals in the nucleus accumbens but not the dorsal striatum corelease glutamate. J. Neurosci. 30, 82298233.

(49) Bao, L., Avshalumov, M. V., Patel, J. C., Lee, C. R., Miller, E. W., Chang, C. J., and Rice, M. E. (2009) Mitochondria are the source of 
hydrogen peroxide for dynamic brain-cell signaling. J. Neurosci. 29, 9002-9010.

(50) Sandri, G., Panfili, E., and Ernster, L. (1990) Hydrogen peroxide production by monoamine oxidase in isolated rat-brain mitochondria: its effect on glutathione levels and $\mathrm{Ca}^{2+}$ efflux. Biochim. Biophys. Acta 1035, 300-305.

(51) Cohen, G., Farooqui, R., and Kesler, N. (1997) Parkinson disease: a new link between monoamine oxidase and mitochondrial electron flow. Proc. Natl. Acad. Sci. U.S.A. 94, 4890-4894.

(52) Levitt, P., Maxwell, G. D., and Pintar, J. E. (1985) Specific cellular expression of monoamine oxidase $\mathrm{B}$ during early stages of quail embryogenesis. Dev. Biol. 110, 346-361.

(53) Zekry, D., Epperson, T. K., and Krause, K. H. (2003) A role for NOX NADPH oxidases in Alzheimer's disease and other types of dementia? IUBMB Life 55, 307-313.

(54) Kishida, K. T., and Klann, E. (2007) Sources and targets of reactive oxygen species in synaptic plasticity and memory. Antioxid. Redox Signaling 9, 233-244.

(55) Miller, E. W., Tulyathan, O., Isacoff, E. Y., and Chang, C. J. (2007) Molecular imaging of hydrogen peroxide produced for cell signaling. Nat. Chem. Biol. 3, 263-267.

(56) Brennan, A. M., Suh, S. W., Won, S. J., Narasimhan, P., Kauppinen, T. M., Lee, H., Edling, Y., Chan, P. H., and Swanson, R. A. (2009) NADPH oxidase is the primary source of superoxide induced by NMDA receptor activation. Nat. Neurosci. 12, 857-863.

(57) Bindokas, V. P., Jordan, J., Lee, C. C., and Miller, R. J. (1996) Superoxide production in rat hippocampal neurons: selective imaging with hydroethidine. J. Neurosci. 16, 1324-1336.

(58) Carriedo, S. G., Sensi, S. L., Yin, H. Z., and Weiss, J. H. (2000) AMPA exposures induce mitochondrial $\mathrm{Ca}^{2+}$ overload and $\mathrm{ROS}$ generation in spinal motor neurons in vitro. J. Neurosci. 20, 240-250.

(59) Lafon-Cazal, M., Pietri, S., Culcasi, M., and Bockaert, J. (1993) NMDA-dependent superoxide production and neurotoxicity. Nature $364,535-537$.

(60) Reynolds, I. J., and Hastings, T. G. (1995) Glutamate induces the production of reactive oxygen species in cultured forebrain neurons following NMDA receptor activation. J. Neurosci. 15, 33183327.

(61) Bienert, G. P., Schjoerring, J. K., and Jahn, T. P. (2006) Membrane transport of hydrogen peroxide. Biochim. Biophys. Acta 1758, 994-1003.

(62) Bienert, G. P., Møller, A. L., Kristiansen, K. A., Schulz, A., Møller, I. M., Schjoerring, J. K., and Jahn, T. P. (2007) Specific aquaporins facilitate the diffusion of hydrogen peroxide across membranes. J. Biol. Chem. 282, 1183-1192.

(63) Avshalumov, M. V., and Rice, M. E. (2003) Activation of ATPsensitive $\mathrm{K}^{+}\left(\mathrm{K}_{\text {ATP }}\right)$ channels by $\mathrm{H}_{2} \mathrm{O}_{2}$ underlies glutamate-dependent inhibition of striatal dopamine release. Proc. Natl. Acad. Sci. U.S.A. 100, 11729-11734.

(64) Mourre, C., Ben Ari, Y., Bernardi, H., Fosset, M., and Lazdunski, M. (1989) Antidiabetic sulfonylureas: localization of binding sites in the brain and effects on the hyperpolarization induced by anoxia in hippocampal slices. Brain Res. 486, 159-164.

(65) Treherne, J. M., and Ashford, M. L. (1991) The regional distribution of sulphonylurea binding sites in rat brain. Neuroscience 40, $523-531$.

(66) Zini, S., Tremblay, E., Pollard, H., Moreau, J., and Ben-Ari, Y. (1993) Regional distribution of sulfonylurea receptors in the brain of rodent and primate. Neuroscience 55, 1085-1091.

(67) Schwanstecher, C., and Panten, U. (1994) Identification of an ATP-sensitive $\mathrm{K}^{+}$channel in spiny neurons of rat caudate nucleus. Pflugers Arch. 427, 187-199.

(68) Dunn-Meynell, A. A., Routh, V. H., McArdle, J. J., and Levin, B. E. (1997) Low-affinity sulfonylurea binding sites reside on neuronal cell bodies in the brain. Brain Res. 745, 1-9.

(69) Dunn-Meynell, A. A., Rawson, N. E., and Levin, B. E. (1998) Distribution and phenotype of neurons containing the ATP-sensitive $\mathrm{K}^{+}$channel in rat brain. Brain Res. 814, 41-54.
(70) Patel, J. C., Witkovsky, P., Coetzee, W. A., and Rice, M. E. (2011) Subsecond regulation of striatal dopamine release by presynaptic $\mathrm{K}_{\text {ATP }}$ channels. J. Neurochem. 118, 721-736.

(71) Nichols, C. G. (2006) $\mathrm{K}_{\mathrm{ATP}}$ channels as molecular sensors of cellular metabolism. Nature 440, 470-476.

(72) Ichinari, K., Kakei, M., Matsuoka, T., Nakashima, H., and Tanaka, H. (1996) Direct activation of the ATP-sensitive potassium channel by oxygen free radicals in guinea-pig ventricular cells: its potentiation by MgADP. J. Mol. Cell. Cardiol. 28, 1867-1877.

(73) Tokube, K., Kiyosue, T., and Arita, M. (1998) Effects of hydroxyl radicals on KATP channels in guinea-pig ventricular myocytes. Pflugers Arch. 437, 155-157.

(74) Clement, J. P., Kunjilwar, K., Gonzalez, G., Schwanstecher, M., Panten, U., Aguilar-Bryan, L., and Bryan, J. (1997) Association and stoichiometry of $\mathrm{K}_{\mathrm{ATP}}$ channel subunits. Neuron 18, 827-838.

(75) Shyng, S., and Nichols, C. G. (1997) Octameric stoichiometry of the $\mathrm{K}_{\text {ATP }}$ channel complex. J. Gen. Physiol. 110, 655-664.

(76) Karschin, C., Ecke, C., Ashcroft, F. M., and Karschin, A. (1997) Overlapping distribution of K-ATP channel-forming Kir6.2 subunit and the sulfonylurea receptor SUR1 in rodent brain. FEBS Lett. 401, 59-64.

(77) Ashcroft, F. M., and Gribble, F. M. (1998) Correlating structure and function in ATP-sensitive $\mathrm{K}^{+}$channels. Trends Neurosci. 21, 288294.

(78) Thomzig, A., Wenzel, M., Karschin, C., Eaton, M. J., Skatchkov, S. N., Karschin, A., and Veh, R. W. (2001) Kir6.1 is the principal poreforming subunit of astrocyte but not neuronal plasma membrane $\mathrm{K}$ ATP channels. Mol. Cell. Neurosci. 18, 671-690.

(79) Babenko, A. P., Aguilar-Bryan, L., and Bryan, J. (1998) A view of SUR/K $\mathrm{K}_{\mathrm{IR}} 6 . \mathrm{X}, \mathrm{K}_{\mathrm{ATP}}$ channels. Annu. Rev. Physiol. 60, 667-687.

(80) Aguilar-Bryan, L., Clement, J. P. T., Gonzalez, G., Kunjilwar, K., Babenko, A., and Bryan, J. (1998) Toward understanding the assembly and structure of $\mathrm{K}_{\text {ATP }}$ channels. Physiol. Rev. 78, 227-245.

(81) Inagaki, N., Gonoi, T., Clement, J. P., Wang, C. Z., AguilarBryan, L., Bryan, J., and Seino, S. (1996) A family of sulfonylurea receptors determines the pharmacological properties of ATP-sensitive $\mathrm{K}^{+}$channels. Neuron 16, 1011-1017.

(82) Babenko, A. P., Gonzalez, G., and Bryan, J. (2000) Pharmacotopology of sulfonylurea receptors. Separate domains of the regulatory subunits of $\mathrm{K}_{\mathrm{ATP}}$ channel isoforms are required for selective interaction with $\mathrm{K}^{+}$channel openers. J. Biol. Chem. 275, 717-720.

(83) Limberger, N., Trout, S. J., Kruk, Z. L., and Starke, K. (1991) Real time" measurement of endogenous dopamine release during short trains of pulses in slices of rat neostriatum and nucleus accumbens: role of autoinhibition. Naunyn-Schmiedeberg's Arch. Pharmacol. 344, $623-629$.

(84) Patel, J., Trout, S. J., and Kruk, Z. L. (1992) Regional differences in evoked dopamine efflux in brain slices of rat anterior and posterior caudate putamen. Naunyn-Schmiedeberg's Arch. Pharmacol. 346, 267276.

(85) Phillips, P. E. M., Hancock, P. J., and Stamford, J. A. (2002) Time window of autoreceptor-mediated inhibition of limbic and striatal dopamine release. Synapse 44, 15-22.

(86) Chen, B. T., Moran, K. A., Avshalumov, M. V., and Rice, M. E. (2006) Limited regulation of somatodendritic dopamine release by voltage-sensitive $\mathrm{Ca}^{2+}$ channels contrasted with strong regulation of axonal dopamine release. J. Neurochem. 96, 645-655.

(87) Zhou, F. M., Liang, Y., and Dani, J. A. (2001) Endogenous nicotinic cholinergic activity regulates dopamine release in the striatum. Nat. Neurosci. 4, 1224-1229.

(88) Rice, M. E., and Cragg, S. J. (2004) Nicotine amplifies rewardrelated dopamine signals in striatum. Nat. Neurosci. 7, 583-584.

(89) Zhang, H., and Sulzer, D. (2004) Frequency-dependent modulation of dopamine release by nicotine. Nat. Neurosci. 7, 581582.

(90) Patel, J. C., Rossignol, E., Rice, M. E., and Machold, R. P. (2012) Opposing regulation of dopaminergic activity and exploratory motor behavior by forebrain and brainstem cholinergic circuits. Nature Commun., DOI: 10.108/ncomms2144. 
(91) Thomzig, A., Prüss, H., and Veh, R. W. (2003) The Kir6.1protein, a pore-forming subunit of ATP-sensitive potassium channels, is prominently expressed by giant cholinergic interneuron in the striatum of the rat brain. Brain Res. 986, 132-138.

(92) Moghaddam, B., Gruen, R. J., Roth, R. H., Bunney, B. S., and Adams, R. N. (1990) Effect of L-glutamate on the release of striatal dopamine: in vivo dialysis and electrochemical studies. Brain Res. 518, $55-60$.

(93) Westerink, B. H., Santiago, M., and De Vries, J. B. (1992) In vivo evidence for a concordant response of terminal and dendritic dopamine release during intranigral infusion of drugs. Naunyn Schmied. Arch. Pharmacol. 345, 523-529.

(94) Barbour, B. (2001) An evaluation of synapse independence. J. Neurosci. 21, 7969-7984.

(95) Bergles, D. E., Diamond, J. S., and Jahr, C. E. (1999) Clearance of glutamate inside the synapse and beyond. Curr. Opin. Neurobiol. 9, 293-298.

(96) Galvan, A., Kuwajima, M., and Smith, Y. (2006) Glutamate and GABA receptors and transporters in the basal ganglia: what does their subsynaptic localization reveal about their function? Neuroscience 143, 351-375.

(97) Rusakov, D. A., Kullmann, D. M., and Stewart, M. G. (1999) Hippocampal synapses: do they talk to their neighbours? Trends Neurosci. 22, 382-388.

(98) Zhang, H., and Sulzer, D. (2003) Glutamate spillover in the striatum depresses dopaminergic transmission by activating group I metabotropic glutamate receptors. J. Neurosci. 23, 10585-10592.

(99) Fujiyama, F., Fritschy, J. M., Stephenson, F. A., and Bolam, J. P. (2000) Synaptic localization of $\mathrm{GABA}_{\mathrm{A}}$ receptor subunits in the striatum of the rat. J. Comp. Neurol. 416, 158-172.

(100) Szabo, B., Muller, T., and Koch, H. (1999) Effects of cannabinoids on dopamine release in the corpus striatum and the nucleus accumbens in vitro. J. Neurochem. 73, 1084-1089.

(101) Sidló, Z., Reggio, P. H., and Rice, M. E. (2008) Inhibition of striatal dopamine release by $\mathrm{CB} 1$ receptor activation requires nonsynaptic communication via $\mathrm{GABA}, \mathrm{H}_{2} \mathrm{O}_{2}$, and $\mathrm{K}_{\mathrm{ATP}}$ channels. Neurochem. Int. 52, 80-88.

(102) Cheer, J. F., Wassum, K. M., Heien, M. L., Phillips, P. E. M., and Wightman, R. M. (2004) Cannabinoids enhance subsecond dopamine release in the nucleus accumbens of awake rats. J. Neurosci. 24, 4393-4400.

(103) Schiemann, J., Schlaudraff, F., Klose, V., Bingmer, M., Seino, S., Magill, P. J., Zaghloul, K. A., Schneider, G., Liss, B., and Roeper, J. (2012) K-ATP channels in dopamine substantia nigra neurons control bursting and novelty-induced exploration. Nat. Neurosci. 15, 12721280.

(104) Bao, L., Avshalumov, M. V., and Rice, M. E. (2005) Partial mitochondrial inhibition causes suppression of striatal dopamine release and depolarization of medium spiny neuron via $\mathrm{H}_{2} \mathrm{O}_{2}$ elevation in the absence of ATP depletion. J. Neurosci. 25, 10029-10040.

(105) Lee, C. R., Witkovsky, P., and Rice, M. E. (2011) Regulation of substantia nigra pars reticulata $\mathrm{GABAergic}$ neuron activity by $\mathrm{H}_{2} \mathrm{O}_{2}$ via flufenamic acid-sensitive channels and K-ATP channels. Front. Syst. Neurosci. 5, 14.

(106) Lee, C. R., Machold, R. P., Witkovsky, P., and Rice. M. E. TRPM2 channels are required for NMDA-induced burst firing and contribute to $\mathrm{H}_{2} \mathrm{O}_{2}$-dependent modulation in substantia nigra pars reticulata GABAergic neurons. J. Neurosci. (in press).

(107) McTaggart, J. S., Clark, R. H., and Ashcroft, F. M. (2010) The role of the $\mathrm{K}_{\mathrm{ATP}}$ channel in glucose homeostasis in health and disease: more than meets the islet. J. Physiol. 588, 3201-3209.

(108) Flagg, T. P., Enkvetchakul, D., Koster, J. C., and Nichols, C. G. (2010) Muscle $K_{\text {ATP }}$ channels: recent insights to energy sensing and myoprotection. Physiol. Rev. 90, 799-829.

(109) Wehage, E., Eisfeld, J., Heiner, I., Jüngling, E., Zitt, C., and Lückhoff, A. (2002) Activation of the cation channel long transient receptor potential channel 2 (LTRPC2) by hydrogen peroxide. A splice variant reveals a mode of activation independent of ADP-ribose. J. Biol. Chem. 277, 23150-23156.
(110) Fleig, A., and Penner, R. (2004) The TRPM ion channel subfamily: molecular, biophysical and functional features. Trends Pharmacol. Sci. 25, 633-639. 